\title{
Ortaöğretim İngilizce Dersi Öğretim Programına \\ Yönelik Durum Çalışması: Öğretmenin Programa Bağlılığı ve Öğrenci Beklentileri
}

\begin{tabular}{lccc}
\hline MAKALE TÜRÜ & Başvuru Tarihi & Kabul Tarihi & Yayım Tarihi \\
Araştırma Makalesi & 25.02 .2020 & 23.05 .2021 & 14.06 .2021 \\
\hline
\end{tabular}

\author{
Esra Civriz
}

Milli Eğitim Bakanlı̆̆

\author{
Sevinç Gelmez Burakgazi (iD) 2 \\ Hacettepe Üniversitesi
}

Öz

Bu araştırmanın amacı, 2017 yılında yenilenen ve kademeli olarak 9. sınıf düzeyinden itibaren uygulamaya konulan 9. sınıf İngilizce dersi öğretim programına yönelik, programa bağlı uygulamalarını yürüten İngilizce öğretmeninin sınıfında öğrenci beklentilerini, dönem sonunda bu beklentilerin karşılanıp karşılanmadığını ve öğrencilerin farklı dil becerilerine yönelik ders başarılarını incelemektir. Araştırma, Kastamonu ilinde bir devlet okulunda 9. sınıf düzeyinde öğrenim gören 65 öğrenci ile gerçekleştirilmiştir. Bütüncül çoklu desenin kullanıldığı bu araştırmada veri, araştırmacılar tarafindan geliştirilmiş öğrencilere yönelik öğrenci beklenti anketi, ara değerlendirme anketi ve son değerlendirme anketi yolu ile toplanmıştır. Doküman analizi kapsamında, İngilizce öğretim programı, öğrenci sınavları ve öğretmen notları incelenmiş; araştırma verileri, betimsel analiz yöntemi ve nicel veri analiz yöntemleri ile çözümlenmiştir. Araştırmadan elde edilen sonuçlara göre, öğrencilerin ortaöğretim 9. sınıf İngilizce dersi öğretim programında, dinleme ve konuşma becerilerine ağırlık verilmesini, canlandırma ve eğitsel oyun gibi etkinliklerin, ders içerisinde diyalog çalışmalarının arttırılmasını, derslerin İngilizce yürütülmesini bekledikleri görülmüştür. Elde edilen bulgulara göre, programın temalarını, planlanan sürede, önerilen etkinlik ve materyallerle destekleyerek yenilenen öğretim programına bağlı derslerini yürüten öğretmenin sınıfinda öğrencilerin beklentilerinin karşılandığı sonucuna ulaşılmıştır.

Anahtar sözcükler: Programa bağl1lık, İngilizce dersi öğretim programı, yabancı dil öğretimi, durum çalışması, İngilizce öğretmenleri

Etik Kurul Kararı: Bu araştırma, Hacettepe Üniversitesi Senatosu Etik Kurulu'nun 01/11/2017-562 tarih ve sayll izni ile uygun bulunmuștur.

\footnotetext{
${ }^{1}$ Öğretmen, Kastamonu/Türkiye, e-posta: esracvrz@ hotmail.com, https://orcid.org/0000-0002-8065-5562 ${ }^{2}$ Dr. Öğrt. Üyesi, Eğitim Fakültesi, Eğitim Bilimleri Bölümü, Eğitim Programları ve Öğretim Anabilim Dal, e-posta: sevincgelmez@ gmail.com, https://orcid.org/0000-0002-4553-1433
} 
Günümüzde bilim, teknoloji ve iletişim alanlarında gözlemlenen hızlı gelişim, dünya üzerindeki sınırları ortadan kaldırmıştır. Küreselleşen dünya düzeninde, toplumların medya, sanayi, kültür, sanat gibi tüm yapıları etkileşim içindedir ve bu sistemde İngilizce, ortak bir payda altında iletişimi sağlamada öne çıkan dildir. Nishanthi (2018), dünyada en yaygın kullanılan dil olan İngilizcenin, farklı ülkelerde yaşayan insanların yanı sıra aynı ülkede yaşayanların da iletişim aracı durumuna geldiğini belirtmiştir. Nishanthi (2018) ve Mckay (2002) İngilizcenin, dünyada en yaygın kullanılan yabancı dil olduğunu belirtmiştir. Bununla birlikte İngilizce bilmenin, yaşama tutunmak için gerekli olduğunu ve bu dilin günümüz dünyasının dışarı açılan ana penceresi olduğunu da belirtmiştir.

Sneddon (2003) küresel bir dil olarak İngilizce'nin, ülkeler arası ekonomik ilişkiler, uluslararası iş ilişkileri, dünya ticareti gibi uluslararası etkileşimde önemli bir rol oynadığını belirtmiştir. Reddy (2016) bu tür etkileşimlerde İngilizce'nin, uluslararası ortak dil görevi üstlendiğini belirtmiştir. Uluslararası alanda yadsınamaz bir öneme sahip olan İngilizce, ülkemizde de iletişim için öne çıkan yabancı dillerdendir. Küreselleşen dünyada İngiliz dilinin konumu, ülkemizde de bu dili bir gereksinim durumuna getirmiştir. Education First (2019) verilerine bakıldığında, İngilizce becerilerinin dünyadaki sıralamasında Türkiye 46.81 puanla "çok düşük yeterlik" göstermekte ve 79. sırada yer almaktadır. Bunun da ülkemizde İngilizceye verilen önemin arttırılması gerekliliğgini ortaya koyduğu söylenebilir. Artan bu önem, öğretim programlarında uluslararası gereksinimler de gözetilerek yenilenme ve değişikliklere gidilme gereksinimi doğurmaktadır.

Milli Eğitim Bakanlığı (2017), bu değişme ve yenilemelerin gerekçesini şöyle açıklamaktadır: Bilim ve teknolojideki hızlı değişmeler, toplum yaşamında bireyden beklenen vasıfların farklılaşmasına neden olmaktadır. $\mathrm{Bu}$ farklılaşma, öğretim programlarında güncellenme ve yenilenme gereksinimini de beraberinde getirmektedir. Öğretim programları çağın gereklerine, bireyin ve toplumun ihtiyaçlarına göre gerekli düzenlemelere tabi tutulabilir.

MEB (2017), öğretim programlarına ilişkin yürütülen değişikliklere yönelik yapmış olduğu basın açılamasında, öğretim programlarında yapılan değiş̧ikliklerin gerekçesini şöyle belirtmiştir: Dünyada ve ülkemizde yaşanan bilimsel ve teknolojik gelişmelerin, bireylerin vasıf örgüsünü ve nitelik dokusunu değiştirdiği, öğrencilere kazandırılması planlanan temel bilgi ve becerilerin yanında öğrenme yaşantılarını edinme sürecinin de önem arz ettiği belirtilmiştir. Ayrıca kazanılmış olan bu özelliklerin yaşamın farklı alanlarında kullanılabilmesi için bireylerin iyi bir donanım ve altyapıya sahip olması da bir gereklilik olarak görülmüştür. Bu gerekçeler doğrultusunda, ortaöğretim 9. sınıf İngilizce dersi öğretim programında, yenilenme yoluna gidildiği görülmüştür. Son yirmi yıl içerisinde 2005, 2012 ve 2017 olmak üzere ortaöğretim İngilizce dersi öğretim programında yenilenme ve değişiklik çalışmaları yürütülmüsştür (MEB, 2005; 2012; 2017). Haznedar (2010), 2005 y1lına kadar yürürlükte kalan İngilizce dersi öğretim programının geleneksel öğretim yaklaşımıla ele alındığını, 2005 yılında yenilenen İngilizce dersi öğretim 
programının ise öğrenci merkezli ve dil öğrenme sürecine odaklı bir program anlayışına hakim olduğunu belirtmiştir. Benzer şekilde Kırkgöz (2008), öğretim programında yenilenme hareketinin bir parçası olarak iletişimsel dil öğretme yaklaşımının tanıtıldığını dile getirmiştir. 2012 İngilizce dersi öğretim programını inceleyen Coşkun-Demirpolat (2015) ise, programdaki en önemli değişikliklerden birinin 12 yıllık zorunlu eğitimle birlikte yabancı dil eğitiminin 2. sınıftan itibaren verilmeye başlanmasının olduğunu belirtmiştir. Kırkgöz (2007), İngilizce'nin Türk eğitim sistemine girdiğinden beri politik ve sosyoekonomik etkenlerden etkilenerek İngiliz dili öğretiminin pek çok değişim geçirdiğini, küreselleşme ile birlikte İngiliz dil politikalarının tüm Türk eğitim sisteminde değerlendirildiğini belirtmiştir. Buradan hareketle 2005 yılından günümüze yenilenen İngilizce öğretim programlarında radikal değişiklikler yapıldığı söylenebilir.

Yenilenen ortaöğretim 9. sınıf İngilizce dersi öğretim programında yapılan değişiklikler incelendiğinde, Yücel, Dimici, Yıldız ve Bümen (2017) İngilizce dersi öğretim programlarında, İngilizce öğretiminde, dünyada yürütülen öğretim model ve yaklaşımlarının, yenilik ve gelişmelerin izlendiği ve yeniliklerin programa dâhil edilmeye çalışıldığını belirtmişlerdir.

2017 y1lında yenilenen öğretim programı, Avrupa Konseyi Ortak Dil Ölçütlerinin eğitimbilimsel (pedagojik) ve betimleyici ilkelerine uygun bir şekilde tasarlanmış ve dil yeterlik düzeyleri belirlenmiştir (MEB, 2017). Eylem odaklı bir yaklaşım benimsenmiş olup "hedeflenen dil ders öğretim aracı olmaktan öteye geçip iletişim aracı özelliği taşımalıdır” hedefi şöyle vurgulanmıştır: "İngilizce Öğretim Programının ana amacı öğrencilerin eğlenceli öğrenme çevresinde güdülenerek, İngilizcenin etkili, akıcı ve özerk bir dil kullanıcıları olabilmeleri için onları İngilizce ile meşgul edebilmektir.” (MEB, 2017, s. 4). Öğretim programının bu amacını gerçekleştirebilmek ve başarılı bir uygulama için öğretmen, öğrenci, yönetici ve uzman gibi tüm paydaşların etkileşim ve iş birliği içerisinde olması büyük önem taşımaktadır.

Ortaöğretim 9. sınıf İngilizce dersi öğretim programı öğeleri incelendiğinde, 2014 ortaöğretim İngilizce dersi öğretim programına göre hedef, tema, öğretmeöğrenme süreci ve ölçme-değerlendirme gibi boyutlarında önemli değişiklikler ve düzenlemeler göze çarpmaktadır. 2017 yılında yenilenen 9. sınıf İngilizce dersi öğretim programı, Avrupa Dilleri Ortak Çerçeve Programının (ADOÇEP), A1 ve A2 düzeyine uyumlu düzenlenmiştir. Bu düzeyde, öğrencilerin öğrendikleri İngilizce bilgisini pekiştirmeleri hedeflenmektedir. Öğrencilerin geliştirmesi gereken beceriler olarak ise; basit konuşmaları anlayabilme, kendini tanıtabilme ve günlük yaşamını hedef dille sürdürebilme becerileridir. Aynı zamanda, Yücel ve diğ. (2017), bu öğretim programının hedeflerinin, üst düzey bilişsel hedefler olduğunu ancak duyuşsal ve psikomotor hedef ile kazanımların öğretim programında yer almadığını, içeriğin, güncel konulardan oluştuğunu ve iletişimsel yaklaşım esas alındığını belirtmişlerdir. 
2014 Ortaöğretim İngilizce Dersi Öğretim Programında içerik sayısı fazla iken, 2017 yılında yenilenen öğretim programında, içeriğin azaltıldığı görülmüştür. Öğretme-öğrenme sürecinde ise öğrencilerin İngilizce iletişim kuran, etkin katılımcı rolü üstlenmeleri hedeflenmiştir. Bu sürecin, etkileşimli bir şekilde "öğrenci-öğrenci, öğrenci-öğretmen şeklinde ve bireysel, eşli ve grupla çalışma aktiviteleri ile yürütülmesi, öğretmenin İngilizceyi etkin kullanması ve iyi bir model olması" esas alınmıştır (MEB, 2017, s. 10). Ayrıca bu süreçte sunulan "materyallerin otantik olması, pek çok dil öğrenme kanalı kullanılarak öğrencide dil öğrenme algısının pekiştirilmesi" hedeflenmiştir. Benzer şekilde, öğrencilerin ilgilerinin yanı sıra "gerçek yaşam dil öğrenme ihtiyaçlarına hitap edilmesi" anlayışı benimsenmiştir. Ortaöğretim İngilizce dersi öğretim programında, dört dil becerisine ağırlık verilmiş ve bu beceriler bir bütün olarak sunulmuştur. Ölçme ve değerlendirmede ise "geleneksel, alternatif yöntemler ve elektronik ölçme ve değerlendirme yöntemlerine" yer verilmiş̧ir. "Dil sınıflarında, her türlü öğrenci ürünü değerlendirilmektedir" ancak öğretim programında, temel ölçme türleri olarak konuşma ve dinleme becerilerini ölçmeye yarayan "Video Bloglar ve Tartışma Zamanı" etkinlikleri sunulmuştur. Dört dil becerisinin bütünleştirilerek ölçülmesinin yanı sıra "dilin kelime, yapı, telaffuz gibi bölümlerinin ölçülmesi teknoloji paketleri, yazılı sınavlar, portfolyolar" aracılığıyla sağlanmıştır (MEB, 2018, s. 10-12). 2005'ten günümüze kadar geliştirilen ortaöğretim İngilizce dersi öğretim programları incelendiğinde, iletişimsel yaklaşıma vurgunun yıllara göre arttığı, daha öğrenci merkezli ve teknolojik materyallerin benimsendiği programlar geliştirildiği düşünülebilir. Yapılan bu değişiklikler, ülkemizde dil öğretiminde modern bir yaklaşımın takip edildiği algısı oluşturabilir.

Gelmez-Burakgazi (2019; 2020), eğitim-öğretimde gerçekleştirilen yenilik çalışmalarının etkili bir şekilde yaşama geçirilmesinin ve eğitim öğretim etkinliklerinin niteliğinin arttırılmasının, büyük oranda uygulamaların öğretim programına bağlılıkla gerçekleştirilebileceğini belirtirken öğretim programına bağlılığı, programın aslına uygun uygulama derecesi olarak tanımlamıştır. Öğretim programına bağlılık, bütünlük ve uygulamanın niteliği olarak da tanımlanmıştır (Dane ve Scheiner, 1998). Dusenbury, Brannigan, Falco ve Hansen (2003), programa bağl1lığı, program geliştirme uzmanları tarafından hedeflenen programın, öğretmenler ve diğer program sağlayıcıların programı uygulama derecesi olarak tanımlamışlardır. Eğitim alanında, öğretim programına bağlılık kavramına ilişkin yaygın kabul edilen görüş ise öğretim programına bağlılı̆̆ı, öğretim programı materyallerinin aslına uygun şekilde doğrusal olarak öğretmen aracıllığılla sunulması olarak tanımlamıștır (Lynch, 2002). Alan yazında sunulan tanımlardan hareketle, öğretim programına bağlılık, tasarlanan / resmi program ile uygulanan programın örtüşmesi olarak tanımlanabilir.

Programa bağlllık beş şekilde ölçülebilir (Dane ve Schneider, 1998; Dusenbury ve diğ., 2003; O’Donnell, 2008): 
1. Programa uyma: Yazılı programla tutarlı bir şekilde belirtilen etkinlik ve yöntemlerin uygulanmas1,

2. Miktar: Katılımcılara sunulan program miktarı, farklı ögeler ile de açıklanabilir (oturum sayısı, katılım oranı, kişi sayısı, süre vb.)

3. Uygulamanın niteliği: Program içeriğinin sunulması açısından program uygulayıcısının, programı saptadı̆̆ı kadarıyla etkililik oranı,

4. Katılımcı tepkileri: Programın içeriğine ve etkinliklere katılan katılımcıların dahil olma ve meşgul olma oranı,

5. Program farklılıkları: Programların ya da farklı oluşumların eşsiz özellikleri, yeni öğretim programını eski programlardan ayıran kendine özgü özellikleri.

Yukarıda sunulan ölçütler doğrultusunda bu çalışmada, öğretmenin programa bağlllığına bu beş öğe çerçevesinde karar verilmiştir. Öğretmen ile rutin görüş̧meler ve öğretmen tarafindan tutulan notların ikinci araştırmacı tarafindan dönem boyunca takibi ile, öğretmenin sınıf içerisinde uygulamış olduğu etkinlik ve yöntemlerin programla tutarlılı̆̆ (uyma), program miktarı (doz), öğretmenin programa ilişkin yürütttü̆̆̈ değerlendirme çalışmaları (uygulamanın niteliği), öğrencilerin ders içi etkinliklere katılımı (katılımcı tepkileri), mevcut programda sunulan yenilikler (program farklılıkları) öğretmenin programa bağlılığı çerçevesinde değerlendirilmiştir.

Öğretim programına bağlılığa ilişkin uluslararası alan yazındaki çalışmalar incelendiğinde, özellikle sağlık ve eğitim alanlarında çalışmaların yürütüldüğ̈̈ dikkat çekmektedir (Backer, 2000; Dane ve Schneider, 1998; Dusenbury ve diğ., 2003; Songer ve Gotwals, 2005).

Programa bağlılık kavramına yönelik yürütülen araştırmalar, politika yapıcılar ile yöneticiler arasında ve politika yapıcıların planları ile öğretmenlerin uygulamaları arasında uygulama farklılıklarının olduğunu, politika yapıcıların genel ve açık uçlu politikalar geliştirirken, öğretmenlerin ise bu politikaları ya da programları uygularken esnek ve özerk olduklarını göstermiş̧tir (Wang, 2006). Benzer şekilde, öğretmenlerin pek çoğunun öğretim programındaki her şeyi sunmadığı, öğretim programına bağlılığın arttırılabilmesi için ise öğretmen eğitiminin, öğretim programının özelliklerinin, öğretmen özelliklerinin ve programın şematik özelliklerinin anahtar görevi gördüğü belirtilmiştir (Dusenbury vd., 2003). Ayrıca, programın uygulanmasında ortaya çıkan sorunları ayrıntılı biçimde incelemek için zaman ve öğrencilerin bölge ve okul düzeyindeki gelişim gereksinimlerini karşılarken, öğretmenlerin mesleki sorumluluklarını yerine getirebilmeleri için desteğe gereksinimlerinin olduğu belirtilmiştir (Roman, 2016).

Araştırmalar, zayıf bir programın yüksek nitelikli uygulamasının, en iyi programın düşük nitelikle uygulanmasından daha etkili olduğunu göstermiştir (Gottfredson, Gottfredson, Czeh, Cantor, Crosse, Hantman, 2000). Programlar, aslina bağlı kalınarak uygulanmalıdır (Arthur ve Blitz, 2000). 
Songer ve Gotwals (2005), programa bağlılık kavramı üzerine öğrencilerle yürütmüş oldukları araştırmalarda, yüksek bağlılığın benimsendiği öğrenci gruplarında, düşük bağlılığın benimsendiği gruplara göre daha yüksek puanlar ve daha fazla kazanımların göze çarptığını ifade etmişlerdir. Ayrıca yüksek bağlılığın benimsendiği gruptaki öğrencilerin, karmaşık düşünme ödevlerinde güçlü bir bilgi ve beceri temeli elde edebileceği belirtilmiştir.

Öğretim programına bağlılığa ilişkin ulusal alanyazında yürütülen çalışma sayısı sınırlıdır (Bümen, Yıldız ve Çakar, 2014; Gelmez-Burakgazi, 2019; 2020). Programa bağlılık kavramı yerine öğretim programı uygulamaları (Öztürk, 2003), öğretim programını kabullenme ve uygulama (Tekbıyık ve Akdeniz 2008), öğretim programının uygulanma düzeyi (Aykaç ve Ulubey, 2012), öğretim programına ilişkin öğretmen ve öğrenci algıları (Şavran, 2017), öğretim programında sunulan kavramların uygulanışına ilişkin öğretmen görüşleri (Baydır, 2018), ve öğretim programının değerlendirilmesi (Yüce, 2018) gibi farklı ifadeleri kullanılmıştır. Yürütülen çalışmalarda ağırlıklı olarak, öğretmenlerin ve öğrencilerin görüşlerine başvurularak program tasarısı ile uygulama arasında farklılık olup olmadığı incelenmiştir. Araştırmalarda öğretmenlerin, görev yaptıkları bölgeye, deneyime ve eğitim durumlarına göre programı uygulamada farklılıklar oluştuğu göze çarpmıştır (Ersen-Yanık, 2007). 2017 yılında yenilenen İngilizce dersi öğretim programında, değerler eğitimi etkinliklerinin ve kazanımlarının yetersiz olduğu, ders saatlerinin azlığı ve öğretmenlerin, öğretim programındaki dil becerilerine ilişkin kazanımları yetiştirmekte güçlük çektikleri görülmüştür (Baydır, 2018).

Araştırmalar doğrultusunda, 2017 yılında yenilenen ortaöğretim İngilizce dersi öğretim programına yönelik gerçekleştirilen program değerlendirme çalışmasında, programın kazanımlarının ADOÇEP'de belirtilen yeterlik düzeyleri ile uyuşmadığı ancak etkinliklerin ögrencilerin dil seviyelerine ve yaşlarına uygun olduğu, programın iletişimsel yaklaşıma ve öğrenci düzeyine uygun olduğu ve hedef dilin kültürel etkinliklerine yer verildiğine değinilmiştir (Yüce, 2018). Program değerlendirme üzerine yürütülen bir diğer çalışmada, 2017 yılında yenilenen 9. Sınıf İngilizce Dersi Öğretim Programının geniş kapsamlı ve işlevsel olduğu ancak öğretme-öğrenme sürecinde iletişimsel yaklaşımı olumsuz etkileyen sınıftaki öğrenci sayılarının fazla olması, farklı tip oturma düzeni oluşturmaya olanak sağlamaması, İngilizcede öğrendiklerini günlük yaşama aktarması beklenen öğrencilerin, İngilizce’yi sınıf ortamında dahi gerçeğe yakın şekilde öğrenme olană̆ı bulamamaları, hedef dille etkileşimin yeterince doğal olmaması gibi pek çok öğenin olduğu belirtilmiştir (Altay, 2018).

Öğretim programlarının, uygulama süreciyle örtüşüp örtüşmediğine, ne derece örtüştüğüne ve uygulamanın programa bağlı olup olmadığına karar verme aşamasında bir uygulayıcı olarak öğretmenlerin yanı sıra öğrenciler de önemlidir. Gürleyik ve Akdemir (2018), öğrencilerin öğrenmesini arttırmak için program geliştirmeyi, program ile ilgili etkinliklerin temel amacı olarak kabul etmişlerdir. Cook-Sather (2006), öğrencilerin, eğitimlerini etkin bir biçimde düzenleyebilmeleri için firsatların 
tanınması gerektiğini ve öğretim programının düzenlenmesi basamağında tartışmalara dahil edilmeleri gerektiğini önermiştir. Bu sayede, öğrencilerin yeni öğretim programına yönelik aidiyet hissedeceklerini de belirtmiştir.

Öğrencilerin programdan beklentileri ile öğretim programının örtüşmesi, öğrencilerin programı benimsemeleri ve olumlu tutum geliștirmeleri için önemli olabilir. Örneğin, öğrencilerin güncel dil gereksinimlerinin, öğretim programına yansıtılması anlamlı olabilir. Böylelikle, öğretim programı, toplumun ve öğrencilerin gereksinimlerine ve beklentilerine uygun olabilir.

İngilizce dersi öğretim programına ilişkin ulusal düzeyde öğrenci beklentilerine yönelik çalışmalarda, programın uygulama sürecinde sınıf ve okulun fiziki koşulları, öğretmen ve öğrenci görüş ve niteliklerinden kaynaklanan farklılar olduğu ancak program hedeflerinin gerçekleştirildiği, içerik seçimi ve düzenlemesinden, ders materyallerinden, programdan kaynaklı birtakım aksaklıklar yaşandığı belirtilmiştir (Ersen-Yanık, 2007). Araştırmalara göre öğrencilerin, kendilerini dört dil becerisinde yeterli hissetmemeleri, öğretmenin sınıf içerisinde Türkçe konuşması ile dil bilgisi ve okumaya ağırlık verilip konuşma becerilerinin sınıf içerisinde ötelenmesi mevcut ortaöğretim İngilizce dersi öğretim programını yetersiz bulmalarına neden olmuştur (Şavran, 2017).

$\mathrm{Bu}$ çalışma, öğrencilerin İngilizce öğretiminden beklentilerinin, İngilizce öğretiminde karşılaştıkları sorunlarının ve bu sorunların nereden kaynaklandığının irdelenmesi açısından önemlidir. Öte yandan, program uygulayıcısı öğretmenin programa bağlılığının sonuçlarının görülmesi bakımından da önemlidir. Özetle, çalışmanın en temel güdüsü, öğretim sürecinin önemli paydaşlarından biri olan öğrencilerin görüşlerinin alınması ve öğretim programına bağlı kalınarak sürdürülen bir öğretimin sonuçlarının incelenmesidir.

Bu çalışma, öğretmenin yenilenen ortaöğretim 9. sınıf İngilizce dersi öğretim programına bağlılık ile ders yürüttüğü sınıflarında öğrencilerin beklentilerinin neler olduğunu, dönem sonunda bu beklentilerin ne kadarının karşılandığını ve öğrencilerin ders başarılarını araştırmayı amaçlamaktadır. $\mathrm{Bu}$ amaç doğrultusunda, araştırma soruları aşağıdaki gibidir:

1. Öğrencilerin ders uygulamalarına yönelik beklentileri nelerdir?

2. Dönem başında, öğrencilerin İngilizce dinleme ve konuşma becerileri programda belirtilen düzeyde midir?

3. Ortaöğretim 9. Sınıf İngilizce Dersi Öğretim Programına öğretmenin bağlılı̆̆ ile yürütülen İngilizce derslerinde dönem sonunda, öğrencilerin yenilenen programa ilişkin beklentileri karşılanmış mıdır?

4. Öğrencilerin İngilizce dinleme, konuşma, okuma ve yazma becerileri dönem sonunda programda belirtilen düzeyde midir? 


\title{
Yöntem
}

Bu bölümde, araştırma modeli, çalışma grubu, veri toplama süreci, veri toplama araçları ve veri analizi sunulmaktadır.

\begin{abstract}
Araştırma Modeli
$\mathrm{Bu}$ çalışmada, nitel araştırma desenlerinden, durum çalışması kullanılmıştır. Creswell (2014), durum çalışmasını süreçleri, etkinlikleri ve eylemleri keşfeden tasarımlar olarak tanımlamıştır. Fraenkel ve Wallen (2012), durum çalışmalarında durumun sadece bir birey, okul, grup ya da programdan oluşabileceğini örneğin, okumayı öğrenmede güçlük çeken bir öğrenci, bir sosyal çalışma sınıfı incelenecek durumlar arasında yer alabilirken, aynı zamanda; özel bir okul ya da öğretim programının incelenmesinin de durum çalışmasına örnek olacağını belirtmişlerdir. Buradan hareketle, 9. Sınıf İngilizce Dersi Öğretim Programında yapılan değişikliklerin ve bu değişikliklerin öğrenciler üzerindeki etkilerinin, öğrencilerin bu programdan beklentilerinin neler olduğunun ve bu beklentilerin karşılanıp karşılanmadığının, öğrencilerin farklı dil becerilerine yönelik ders başarılarının derinlemesine incelenmek ve araştırılmak istendiği bu çalışmada, durum çalışması kullanılmıştır. Durum çalışması desenlerinden ise "bütüncül çoklu durum deseni" kullanılmıştır. Yin (2003) bütüncül çoklu durum desenini, her bir durumun öncelikle kendi içinde bütüncül bir şekilde ele alınması daha sonra ise durumların birbiriyle karşılaştırılması olarak tanımlamıştır. Bu çalışmada, araştırmanın yürütüldüğü sınıflar durum olarak nitelendirilmiş, bütüncül olarak ele alınmış ve sonrasında durumlar birbirleri arasında karşılaştırılmıştır. Bu nedenle; bu desen kullanılmıştır. Bu sayede 2017 y1lı program değişikliğinin hemen üzerine öğrenci beklentileri, öğretmen uygulamaları ve takibi üzerine veri elde edilmiştir. Sınıf içerisinde öğretmen uygulamaları ve öğretmen notları, öğretmenin programa bağlılığına 1şık tutmuştur.
\end{abstract}

\section{Çalışma Grubu}

Bu çalışma, 2017-2018 eğitim-öğretim yılı birinci döneminde Kastamonu'da bir ortaöğretim kurumunda öğrenim gören 9. sınıf öğrencileri ile gerçekleştirilmiştir. 2017 yılında uygulamaya konan İngilizce dersi öğretim programı kademeli olarak öncelikli olarak 9. sinıflarda, sonraki yıllarda ise 10,11 ve 12 sinıflarda uygulanmaya başlamak üzere 2017 yılında yürürlüğe girmiştir (MEB, 2017). Bu nedenle bu çalışmada, 2017 yılında uygulamaya konan sadece 9. sınıf düzeyinde değişikliklerin yapıldığı öğretim programı temel alınmıştır ve 9. sınıflarla çalışma yürütülmüştür. Çalışma grubu, öğretmenin görev yaptığı okulda ve ders verdiği sınıflarda gerçekleştirilmiş olması nedeniyle amaçlı örnekleme yöntemlerinden "kolay ulaşılabilir durum örnekleme" yolu ile belirlenmiştir. Bu bağlamda, bu çalışmada 9 . Sınıf İngilizce Dersi Öğretim Programına yönelik öğrenci beklentileri araştırıldığı için çalışma, sadece 9. sınıf öğrencileri ile yürütülmüştür. Çalışmanın katılımcıları, 9. sınıf düzeyinde iki ayrı şubede öğrenim gören 21 erkek ve 44 kadın olmak üzere 65 öğrenciden oluşmuştur. 
ADOÇEP' e göre öğrencilerin İngilizce dil seviyeleri, bu düzeyde A1 düzeyinde olmalıdır. Çalışmanın yürütüldüğü sınıfların fiziki koşulları incelendiğinde, sınıflarda akıllı tahta gibi etkileşimli materyallerin olmadığı göze çarpmaktadır. Olumsuz fiziki koşullar nedeniyle, dönem içerisinde öğretmen, dinleme ve bazı uygulama çalışmalarını kişisel bilgisayarını kullanarak yürütmüştür. $\mathrm{Bu}$ olumsuz fiziki koşulların yanında, okulda eTwinning ve Erasmus+ proje başvurularının ve çalışmalarının yürütüldüğü öğrenilmiştir. Bu durum okulun, uluslararası düzeyde işbirliğine verdiği önemi ortaya koyarak, öğretmenlerin mesleki gelişimleri açısından önemli bir firsat olarak düşünülebilir.

\section{Veri Toplama Araçları}

Bu çalışmada, öğrencilere yönelik öğrenci beklenti anketi, dönem başı dinleme ve konuşma sınavları, ara değerlendirme formu, iki yazılı sınav, bir uygulama sınavı ve son değerlendirme anketi kullanılmıştır. Ek olarak, öğretmen notlarından yararlanılmıştır. Bu veri toplama araçlarının son şeklinin verilmesi amacıyla soruların kapsamı, açıklayıcılığı, anlaşılırlığı ve varsa önerileri üzerine iki uzmanın görüşü alınmıştır. Uzmanların ikisi de Ankara'da bulunan bir devlet üniversitesinde Eğitim Programları ve Öğretim Anabilim Dalında lisansüstü programa kayıtlı olup, biri aynı zamanda bir ortaöğretim kurumunda İngilizce öğretmenidir. Diğer uzman ise bir kamu üniversitesinde İngilizce okutmanı olarak görev yapmaktadır. Uzmanların her ikisi de mesleklerinde beş y1llık deneyime sahiptir.

Aşağıda, öğrenci beklentisine ilişkin çalışmada uygulanan veri toplama araçları ayrıntılı olarak açıklanmıştır:

Dönem başında uygulanan veri toplama araçları. Bu adımda, öğrenci beklenti anketi, dinleme ve konuşma sınavları uygulanmıştır.

Öğrenci beklenti anketi, dönem başında öğretmen tarafından uygulanmış olup, ilk kısmında öğrencilerin demografik özelliklerine yönelik soruları içermektedir (Cinsiyet ve öğrencilerin 8. sınıf İngilizce not ortalamaları). Anket iki açık uçlu soru (Ders sırasında hangi etkinliklerin kullanılmasını tercih ederdiniz?; Dönem sonunda Ingilizce dersinde hangi yeterlikleri kazanmayı bekliyorsunuz?) ve iki çok seçenekli soru (Ingilizce dersinde aşağıdaki yeterliklerden hangilerinde kendinizi daha rahat hissediyorsunuz?; Aşă̆ıda bulunan uygulamalardan hangileri ders sırasında kullanılmaktadır?) olmak üzere toplam dört maddeden oluşmaktadır. Anket dönem başında uygulanmış olup, uygulama yaklaşık 15 dakika sürmüştür.

Ayrıca dönem başında öğretmen tarafından uygulanan, öğrencilerin dinleme ve konuşma becerilerine yönelik iki kısa sınav hazırlanmıştır.

Dinleme becerisini ölçmeye yönelik şarkı (Titanic by Celine Dion) dinletilip şarkının içerisinde bulunan ders içeriğine yönelik bazı ifadeler (you, go on, here, know, open, lifetime, life, my) çıkarılarak boşluk doldurma yaptırılmış, şarkı1ı iki kez dinlemeleri sağlanmıştır. Uygulama yaklaşık 10 dakika sürmüştür. Konuşma becerisine yönelik ise (9. Sinıf Teenwise kitabı 2. Ünite "Directions") öğretmen 
tarafından hazırlanan harita üzerinden, öğrencilerden yer-yön tarif etmeleri istenmiştir. Bireysel olarak gerçekleştirilen bu kısa sözlü sınavda öğrencilerin yer-yön tarifi ortalama 2-3 dakika sürmüş olup, uygulama beş ders saatinde tamamlanmıştır.

Dönem ortasında uygulanan veri toplama araçları. Ara değerlendirme formu ve iki yazılı sınav kullanılmıştır.

Ara değerlendirme formunda iki açık uçlu soruyu (Ingilizce derslerinde gerçekleştirilen role play, diyalog olușturma vb. gibi etkinlikleri nasll buluyorsun?; Dersin ögretmeni siz olsa idiniz ders ile ilgili ne gibi değişiklikler yapmak isterdiniz?) yanıtlamaları istenmiştir. Uygulama yaklaşık 10 dakika sürmüştür.

Yazılı sınavlarda ise, öğrencilere okuma becerisine yönelik metin verilip okuduğunu anlama ve doğru/yanlış bulma şeklinde sorular yöneltilmiş; yazma becerisine yönelik ise soy ağacı verilip aile üyelerini tanıtmaları istenmiştir. Yazılı sınav soruları MEB'in 9. sınıf "Teenwise" İngilizce ders kitabının birinci ve ikinci ünitesine yönelik hazırlanmışıtır. Yazılı sınavlar, bir ders saatinde tamamlanmıştır.

Dönem Sonunda Uygulanan Veri Toplama Araçları. Dört dil becerisine yönelik uygulama sınavı yapılmış ve öğrencilerin beklentilerinin karşılanıp-karşıllanmadığına, öğretim programına ne ölçüde bağlı kalındığına ilişkin son değerlendirme anketi uygulanmıştır.

Son değerlendirme anketinde yedi açık uçlu soru (Ingilizce dersinde aşağıdaki yeterliklerden hangilerinde kendinizi daha rahat hissediyorsunuz? Dinleme/Konuşma/Okuma/Yazma; Bu dönem katıldı̆̆ın İngilizce dersleri geçmiş dönemlerde katıldiğın İngilizce derslerinden nasıl farklllaşmaktadır?; Dönem sonunda İngilizce dersinde hangi yeterlikleri kazandığınızı düşünüyorsunuz?; Dönem boyunca öğrenmenizi kolaylaştıran etkinlikler nelerdi?; Ders beklentilerinizi karşıladı mı?; Ders ile ilgili en çok hoşlandığınız şeyler nelerdi?; Ders ile ilgili hoşlanmadığınız şeyler nelerdir?) bulunmaktadır. Anket sorularının yanıtlanması yaklaşık 15 dakika sürmüştür.

Uygulama sınavında konuşma becerisine yönelik (my environment: there isthere are, bookshop, pharmacy, bedroom, living room, vb.) öğrencinin kendi çevresinden ve mahallesinden söz etmesi istenmiştir. Konuşma metinleri de yine 9. sınıf Teenwise İngilizce kitabının içeriğine uygun olarak düzenlenmiştir. $\mathrm{Bu}$ uygulama sınavı altı ders saati sürmüştür. Dinleme becerisine yönelik ise şarkı (One Big Family-Maher Zain) dinletilip bazı sözcükler ( brother, family, why, you,vb.) boş bırakılarak öğrencilerin doldurmaları istenmiştir. Boşluk doldurma kısmında seçilen sözcükler, üzerinde ders sırasında yapılan etkinliklerle desteklenmiş sözcüklerdir. Okuma becerisine yönelik 1, 2, 3 ve 4. ünitelerin sözcük ve yapılarını kapsayan bir okuma metni verilmiştir. Yazma becerisine yönelik ise karşılaştırma cümleleri kurmaları istenmiştir.

Dönem boyunca öğretmenin derslerine yönelik aldığı notları da doküman incelemesi kapsamında kullanılmıştır. Ders notları, öğretmenin programa bağlılığına 
karar vermede bir veri toplama aracı olarak kullanılmıştır. Genel olarak ders notlarında, ders girişinde kullanılan derse hazırlık etkinlikleri, ders içerikleri, derste uygulanan etkinliklerin kısa özeti, derste kullanılan materyal ve ders sonunda yapılan değerlendirme çalışmaları ve kazanımlar yer almaktadır.

\section{Veri Toplama Süreçleri}

Çalışma, 2017-2018 eğitim-öğretim y1lı güz döneminde yürütülmüştür. Bu çalışma, Hacettepe Üniversitesi Senatosu Etik Kurulu'nun 01/11/2017-562 tarih ve sayılı izni ile uygun bulunmuştur. İlgili izinlerin alınmasının ardından uygulama sürecine geçilmiştir. Uygulamalar, öğrencilere yönelik öğrenci beklenti anketi ile dinleme ve konuşma becerilerine yönelik düzzey belirlemek için iki kısa sınav uygulaması ile başlatılmışıır. Bir ay sonra ara değerlendirme formu uygulanmış, arkasından ilk yazılı sınav uygulanmıştır. Dönem sonunda, ikinci yazılı sınav uygulanıp ardından uygulama sınavı gerçekleştirilmiştir. Öğrencilerin her biri ile ayrı ayrı uygulama sınavı gerçekleştirilerek dinleme ve konuşma becerilerinin hangi düzeye ulaşıı̆ına bakılmıştır. Söz konusu dokümanlarda öğrencilerin her birine ve öğretmene kodlar atanmış (Ö1: Öğrenci 1; Ö2: Öğrenci 2; Öğretmen T. gibi) ve ilk sınav - son sınav ya da uygulamalar arasındaki farklar incelenmiştir. Dönem sonunda da ögrencilerin beklentilerinin ne derecede gerçekleştiğine yönelik bir anket kullanılmıştır. Dönem sonunda, öğretmenin dönem içerisindeki uygulamalarına yönelik almış olduğu notlar incelenmiş ve programa bağlılına 1şık tutacak veriler, öğretmen notlarından elde edilmiştir.

\section{Verilerin Analizi}

$\mathrm{Bu}$ çalışmada anket ve değerlendirme formundaki açık uçlu sorulara verilen yanıtlar, betimsel analiz yolu ile çözümlenmiştir. Bu analiz türünde veriler genellikle araştırma sorularına göre gruplandırılabilir. Yıldırım ve Şimşek (2003), bu analiz türünün amacını "ham haldeki verilerin okuyucuların anlayabileceği ve isterlerse kullanabileceği bir şekle sokulmasıdır" olarak belirtir (s. 268). Buradan hareketle bulguların sunumunda, öğrenci beklentilerini yansıtan ifadelere sıklıkla başvurulmuştur ve bire bir alıntılama yapılmıştır. Böylelikle, çalışmanın güvenilirliğine yönelik katkı sağlamıştır. Nicel verilerin analizinde SPSS 23 paket programı kullanılmıştır.

Çalışmanın inandırıcılığını sağlamak üzere çeşitli stratejiler izlenmiştir. Guba ve Lincoln'e (1982) göre inandırıcılık için inanılırlık, aktarılabilirlik, güvenilebilirlik ve onaylanabilirlik önemlidir. İnanıılırlı için, veri toplama araçları ile ilgili uzman görüşü alınmıştır, veri toplama süreci öncesinde pilot çalışma yapılmıştır. Pilot çalışma, yine bir meslek lisesinde 9. sınıfa yeni başlayan 30 öğrenci ile yürütülmüștür. $\mathrm{Bu}$ çalışmalar sonucunda veri toplama araçları uygulamaya hazır hale getirilmiştir. Sürecin başından sonuna zengin bir şekilde ayrıntılandırılarak sunulması ve amaçlı örnekleme yöntemi, aktarılabilirlik; ayrıca çeşitli veri toplama araçlarının uzman görüşü ile izlenmesi ve kişilerden alıntıların kullanılması, çalışmanın güvenilebilirliği ve onaylanabilirliği açısından önemli öğelerdir. 
Araştırmacı rolü. Sınıfın öğretmeni, aynı zamanda ilk araştırmacı olup, İngiliz dili Öğretmenliği Programı mezunudur, üç yıllık deneyime sahiptir. Öğretmenin, çalışmanın yürütüldüğü okulda ise ilk yılıdır. Araştırmacı, grubun öğretmeni olması dolayısıyla da çalışmanın yapıldığı ortamda bizzat bulunmuş, veri toplama sürecini kendisi gerçekleştirmiş ve veri toplama sürecine yeterli süre ayırarak bulguları önyargılardan uzak nesnel, ayrıntılı ve katılımcılardan alıntılara yer vererek sunmuştur. İkinci araştırmacı, Eğitim Programları ve Öğretim Anabilim Dalı'nda çalışmaları ile sekiz yıllık mesleki deneyime sahiptir. Tüm aşamalar, iki araştırmacı arasında iş birliği, görüş birliği ve görüşmeler ile yürütülmüştür.

\section{Bulgular}

$\mathrm{Bu}$ bölümde araştırma süreci boyunca elde edilen bulgular araştırma soruları ölçüt alınarak sunulmuştur.

1. 2017 Yılında Yenilenen Ortaöğretim 9. Sınıf İngilizce Dersi Öğretim Programına İlişkin Öğrenci Beklentileri ve Görüşlerine Yönelik Bulgular

Tablo 1'de öğrencilere dönem başında uygulanan öğrenci beklenti anketine ilişkin bulgular sunulmuştur.

Tablo 1

Öğrencilerin Bir Önceki Dönem İngilizce Notlarına İlişkin Dă̆llımları

\begin{tabular}{lcc}
\hline Not Dağllımları & f & \% \\
\hline $90-100$ & 32 & 49.0 \\
$80-89$ & 16 & 25.0 \\
$70-79$ & 14 & 21.0 \\
$60-69$ & 2 & 3.0 \\
$40-49$ & 1 & 2.0 \\
\hline
\end{tabular}

Tablo 1'de öğrencilerin bir önceki öğretim yılında İngilizce dersinden aldıkları notlara ilişkin veriler gösterilmektedir. $\mathrm{Bu}$ bilgiler incelendiğinde, öğrencilerin 32'sinin 90-100, 16'sının 80-89, 14'ünün 70-79, ikisinin 60-69 ve birinin 40-49 aralığında bir İngilizce notuna sahip olduğu görülmüştür.

Dönem başında uygulanan öğrenci beklenti anketine ilişkin diğer bir bulgu ise şöyledir; erkek öğrencilerin İngilizce not ortalamalarının yaklaşık 84 olduğu görülürken, kadın öğrencilerin İngilizce not ortalamalarının yaklaşık 86 olduğu görülmektedir. Öğrencilerin İngilizce not ortalamaları incelendiğinde, kadın öğrencilerin erkek öğrencilere göre daha yüksek not ortalamasına sahip oldukları görülmüştür. Tablo 2'de öğrencilerin İngilizce dersinde kendilerini daha iyi hissettikleri beceriler sunulmuştur. 
Tablo 2

Öğrencilerin İngilizce Dersinde Kendilerini Daha İyi Hissettikleri Beceriler

\begin{tabular}{lcc}
\hline Yeterlik & f & \% \\
\hline Dinleme & 19 & 29 \\
Sözcük bilgisi & 14 & 20 \\
Konuşma & 13 & 21 \\
Yazma & 11 & 18 \\
Okuma & 5 & 7 \\
Diğer & 3 & 5 \\
\hline
\end{tabular}

Tablo 2'de araştırmaya katılan 9. sınıf öğrencilerinin İngilizce dersinde hangi yeterlikte kendilerini daha iyi hissettiklerine ilişkin soruya verdikleri yanıtlar gösterilmiştir. S1klıklara bakıldığında, 65 öğrenciden 19'unun dinleme, 14'ünün sözcük bilgisi ve 13'ünün konuşma becerilerinde kendilerini rahat hissettikleri görülmektedir. Yazma becerisini 11, okuma becerisini beş öğrencinin tercih ettiği görülmektedir. Bu bilgilere göre, öğrencilerin kendilerini en çok dinleme, konuşma becerilerinde ve sözcük bilgisinde rahat hissettikleri anlaşılmaktadır. Öğrencilerin, dinleme ve konuşma becerisine yönelik ders kapsamında yürütülmesini istedikleri etkinlikler Tablo 3 'te sunulmuştur.

Tablo 3

Öğrencilerin Ders Kapsamında Yürütülmesini İstedikleri Etkinlikler

\begin{tabular}{lcc}
\hline Uygulamalar & f & $\%$ \\
\hline Tartışma zamanı & 47 & 60 \\
Çevrimiçi materyal & 24 & 30 \\
Haftanın atasözü & 3 & 4 \\
Çevrimiçi ürün dosyası & 2 & 3 \\
Çevrimiçi paylaşım sitesi & 2 & 3 \\
\hline
\end{tabular}

Tablo 3'te araştırmaya katılan 9. sınıf öğrencilerinin İngilizce dersinde dönem boyunca kullanılmasını istedikleri etkinliklere ilişkin verdikleri yanıtlar gösterilmiştir. Sıklıklar incelendiğinde, 65 öğrenciden 47'sinin tartışma zamanı, 24'ünün çevrimiçi materyal, üçünün haftanın atasözü, ikisinin çevrimiçi ürün dosyası ve ikisinin çevrimiçi paylaşım sitesi uygulamasının kullanılmasını istedikleri görülmüştür. Bu bilgilere göre öğrencilerin ders kapsamında yürütülmesini istedikleri etkinliklerin başında tartışma zamanı ve çevrimiçi materyal etkinlikleri gelmektedir. Buradan hareketle öğrencilerin çoğunluğunun $(\% 60)$, dönem boyunca ders kapsamında uygulanabilecek etkinliklerden birinin tartışma zamanı olmasını istedikleri görülmüştür. Benzer şekilde öğrencilerin dönem boyunca İngilizce derslerinde kullanılmasını bekledikleri etkinlikler Tablo 4'te sunulmuştur 
Tablo 4

Ders Sirasında Kullanılması Tercih Edilen Etkinlikler

\begin{tabular}{lcc}
\hline Etkinlikler & f & \% \\
\hline Canlandırma yapılması & 42 & 65 \\
Sözcük yarışması (oyun) & 12 & 19 \\
Sesletim & 6 & 9 \\
Konuşma & 3 & 5 \\
Ödev verilmesi & 1 & 1 \\
İngilizce şarkı söylemek & 1 & 1 \\
\hline
\end{tabular}

Tablo 4’te öğrencilere “Ders sırasında hangi etkinliklerin kullanılmasını tercih ederdiniz?" sorusu yöneltilmiş ve yanıtlara ilişkin sonuçlar sunulmuştur. Sıklıklar incelendiğinde 65 öğrencinin 42'si canlandırma yapılması, 12'si sözcük yarışması (oyun), altısı sesletim, üçü konuşma, biri Íngilizce şarkı söylemek, biri ödev verilmesi, çalışmalarının yapılmasını tercih ettiklerini belirtmiştir. Bu bilgilere göre öğrencilerin ders sırasında kullanılmasını en fazla istedikleri etkinliklerin canlandırma yapılması ve oyun şeklinde olduğu anlaşılmaktadır. Bulgulara yönelik alıntılar aşağıda sunulmaktadir:

“Oyun oynamak kelime haznemi geliştiriyor.”(Ö5)

“Derste canlandırma yapılırsa daha kalıcı olur.”(Ö18)

“İngilizce oyun oynamak, çünkü beni rahatlatır.” (Ö25)

Tablo 5

Kazanılması Düşünülen Yeterliklere İlişkin Dă̆llımlar

\begin{tabular}{lcc}
\hline Yeterlikler & f & $\%$ \\
\hline Konuşma & 25 & 32 \\
Okuma & 7 & 10 \\
Dinleme & 5 & 6 \\
Yazma & 5 & 6 \\
Konuşma ve dinleme & 10 & 14 \\
Okuma ve dinleme & 5 & 6 \\
Konuşma ve yazma & 5 & 6 \\
Dinleme ve sözcük bilgisi & 4 & 5 \\
Okuma ve yazma & 3 & 4 \\
Konuşma, okuma ve dinleme & 5 & 6 \\
Konuşma, okuma ve yazma & 1 & 2 \\
Konuşma, okuma, dinleme, yazma & 2 & 3 \\
\hline
\end{tabular}

Tablo 5'te öğrencilerin “Dönem sonunda kazanılmasını düşündüğünüz yeterlikler nelerdir?" sorusuna vermiş oldukları yanıtlar sunulmuştur. Sıklıklar incelendiğinde, 65 öğrenciden 25'inin sadece konuşma, yedisinin sadece okuma, beşinin yazma ve beşinin sadece dinleme becerilerini kazanmayı bekledikleri görülmektedir. İki veya daha fazla beceriyi kazanmayı hedefleyen öğrenci sayılarına 
bakıldığında 10'unun konuşma ve dinleme, beşinin konuşma ve yazma, beşinin okuma ve dinleme, dördünün dinleme ve sözcük bilgisi, üçünün okuma ve yazma, beşinin konuşma, okuma ve dinleme, birinin konuşma, okuma ve yazma, ikisinin ise konuşma, okuma, dinleme ve yazma becerilerinin dördünü de kazanmayı hedeflediği görülmektedir. Tabloda sunulan bilgilere göre öğrencilerin dönem sonunda kazanmayı en fazla beklediği yeterliliğin İngilizce konuşma becerisi olduğu anlaşılmaktadır. Bu görüşü destekleyen öğrenci görüşlerinden bir bölümü aşağıda sunulmuştur:

"İngilizce konuşmayı istiyorum. Çünkü farklı bir dil öğreniyoruz. Hocamız hep İngilizce konuşuyor. Ondan da özeniyorum.’(Ö1)

"Kelime haznemin gelişmesini ve daha rahat İngilizce konuşmayı hedefliyorum.”(Ö8)

"Kendi dilim gibi hızlı ve düzgün konuşmak isterim, dinlediğim şarkıların anlamlarını bilmek ve söylemek isterim.”(Ö51)

“Akııı bir şekilde İngilizce konuşmak ve yabancı bir şarkı dinlediğimde anlamak isterim.”(Ö55)

Bu bölümde "Ara Değerlendirme Formuna” ilişkin bulgular sunulmuştur. Ara Değerlendirme Formunda yer alan "İngilizce dersinde gerçekleştirilen etkinlikleri (role play, diyalog oluşturma vb.) nasıl buluyorsun?" sorusuna verilen öğrenci yanıtları incelendiğinde 65 öğrenciden 46'sı ders içi etkinlikleri uygun bulduğunu, 19'u ise geliştirilebilir bulduklarını belirtmiş̧tir. Buradan hareketle, öğrencilerin çoğunluğunun $(\mathrm{f}=46)$ ders içerisinde gerçekleştirilen etkinliklerden memnun olduğu düşünülebilir. Öğrencilerin İngilizce dersinde gerçekleştirilen etkinliklerin geliştirilmesine yönelik önerileri Tablo 6'da verilmiştir.

Tablo 6

Öğrencilerin Ingilizce Dersinde Gerçekleştirilen Etkinliklerin Geliştirilmesine Yönelik Önerileri

\begin{tabular}{lcc}
\hline Etkinlik Önerileri & f & \% \\
\hline Diyalogları arttırarak & 9 & 47 \\
Daha fazla etkinlik yaparak & 7 & 37 \\
Daha fazla görsel materyal kullanılarak & 2 & 11 \\
Oyun çeşitliliğini arttırarak & 1 & 5 \\
\hline
\end{tabular}

Tablo 6'da görüldüğü üzere araştırmaya katılan öğrencilerin “Íngilizce dersinde gerçekleştirilen etkinlikleri nasıl geliştirebiliriz?” açık uçlu sorusuna verdikleri yanıtlar incelendiğinde, İngilizce dersindeki etkinlikleri geliştirilebilir olarak değerlendiren dokuz öğrencinin diyalogları arttırarak, yedi öğrencinin daha fazla etkinlik yaparak, iki ögrencinin daha fazla görsel materyal kullanarak ve bir öğrencinin ise oyun çeşitliliğini arttırarak şeklinde yanıt verdikleri görülmüştür. Bu 
bilgilere göre öğrencilerin çoğunluğu, diyalogları artırarak veya daha fazla etkinlik yaparak İngilizceyi geliştirilebileceğini düşünmektedir. $\mathrm{Bu}$ görüşü destekleyen öğrenci görüşlerinden bir bölümü şöyledir:

“Tiyatro yapılarak hem görsel hem de işitsel akılda kalıcı oluyor.”(Ö22)

"Daha fazla etkinlik ile daha eğlenceli bir hale getirilebilir."(Ö58)

"Daha fazla görselle desteklerdim.”(Ö62)

Araştırmaya katılan öğrencilerin "İngilizce dersinde gerçekleştirilen etkinlikler uygun mu?" sorusuna verdikleri yanıtlar incelendiğinde İngilizce dersinde yapılan etkinlikleri uygun olarak değerlendiren 13 öğrenci etkinlikleri güzel ve öğretici olarak değerlendirmiş ve 33 öğrenci etkinliklerin kalıcl ve etkili olduğunu belirtmiştir. $\mathrm{Bu}$ bilgilere göre araştırmaya katılan öğrenciler, etkinliklerin uygun, kalıcı ve öğretici olduğunu düşünmektedir. Katılımcılardan Ö32 ve Ö35’ten bu görüş doğrultusunda alıntılar sunulmuştur:

"Bu uygulamalar hem dinleme hem de konuşma becerimizi geliştiriyor.”(Ö32)

"Hocayla İngilizce konuşmamız bizi daha olumlu etkiliyor ve kelimelere aşina olmamızı sağlıyor kolayca İngilizce öğrenebiliyoruz.”(Ö35)

Tablo 7

Dersle İlgili Öğrencilerin Önerdiği Değişikliklere İlişkin Dağılımlar

\begin{tabular}{lcc}
\hline Öğrencilerin Önerileri & f & \% \\
\hline Değişiklik yapmazdım & 31 & 48 \\
Etkinlikler eklerdim & 15 & 22 \\
Öğrencilere uygulama yaptırırdım & 7 & 11 \\
Türkçe konuşmazdım & 6 & 9 \\
Görsel materyal kullanırdım & 3 & 4 \\
Dersi Türkçe anlatırdım & 1 & 2 \\
Rahatlık ve özgürlük getirirdim & 1 & 2 \\
Sınıfları birleştirir tekinlik yapardım & 1 & 2 \\
\hline
\end{tabular}

Tablo 7'de araştırmaya katılan öğrencilerin "Dersin öğretmeni olsa idiniz ne gibi değişiklikler yapmak isterdiniz?" sorusuna ilişkin verdikleri yanıtlar gösterilmiştir. $\mathrm{Bu}$ dağılımlar incelendiğinde 65 öğrenciden 31'i değişiklik yapmazdım, 15'i etkinlikler eklerdim ve yedisi ögrencilere uygulama yaptırırdım şeklinde yanıt vermişlerdir. Verilen yanıtlar incelendiğginde, öğrenciler altısı ders içerisinde Türkçe konuşmazdım, üçü görsel materyal kullanırdım, biri dersleri Türkçe anlatırdım, biri rahatllk ve özgürlük getirirdim ve biri sinıfları birleştirir etkinlik yaptırırdım gibi yanıtlar vermişlerdir. Bu bilgilere göre öğrencilerin çoğunluğunun $(\mathrm{f}=31)$, dersin öğretmeni olsalardı değişiklik yapmayacaklarını, öğretmeni nasıl ders işliyorsa aynı şekilde ders işleyeceğini, değişiklik yapmak isteyen öğrencilerin ( $\mathrm{f}=34)$ ise etkinlikler 
eklerdim veya öğrencilere uygulama yaptırırdım şeklinde yanıt verdikleri görülmüştür. Aşağıda bu görüşleri destekleyen alıntılara yer verilmiştir:

"Akılda kalıcı yöntemler kullanırdım. Haftada bir ders oyun ve o konu ile ilgili etkinlik yapardım.”(Ö5)

"Dikkat çekici yazı, görsel, karikatür gibi şeyler kullanıp dersi daha eğlenceli hale getirirdim.”(Ö13)

"Etkinlikleri artırırdım böylece öğrencilerin dersi daha fazla sevmesine yardımc1 oluruz."(Ö21)

“Öğretmenimiz gibi İngilizce konuşurdum.”(Ö28)

2. Dönem Sonunda Öğretmenin Programa Bağlı Olarak Yürüttüğü İngilizce Derslerinde Öğrencilerin Yenilenen Ortaöğretim 9. Sınıf İngilizce Dersi Öğretim Programına İlişkin Beklentilerinin Karşılanmasına İliş̧kin Bulgular

$\mathrm{Bu}$ araştırmada öğretmenin programa bağlılığı, Dane ve Schneider (1998), Dusenbury ve arkadaşları (2003) ve O'Donnell (2008) tarafindan belirlenen beş ölçütten dördü temel alınarak ölçülmüştür. Bu dört ölçüt incelendiğinde, (1) Programa uyma: Yazılı programla tutarlı biçimde belirtilen etkinlik ve yöntemlerin uygulanması, (2) Miktar: Katılımcılara sunulan program miktarı, farklı öğeler ile de açıklanabilir (oturum sayısı, katılım oranı, kişi sayısı, süre vb.), (3) Uygulamanın niteliği: Program içeriğinin sunulması açısından program uygulayıcısının, programı saptadığı kadarıyla etkililik oranı, (4) Katılımcıların tepkileri: Programın içeriğine ve etkinliklere katılan katılımcıların dahil olma ve meşgul olma oranı. Bu bağlamda Tablo 8'de öğretmenin programa bağlılığına ilişkin notları sunulmuştur.

Tablo 8

Ögrretmen Notlart

\begin{tabular}{lccc} 
Temalar & $\begin{array}{c}\text { Yararlanılan } \\
\text { Kaynaklar }\end{array}$ & $\begin{array}{c}\text { Yıllık Planda } \\
\text { Unitelere Ayrıan } \\
\text { Ders Saatleri }\end{array}$ & $\begin{array}{c}\text { Çalsşmalar/Kullanılan } \\
\text { Ögretim Yöntem ve } \\
\text { Teknikleri, Materyaller }\end{array}$ \\
\hline Studying Abroad & Teenwise & 20 saat & $\begin{array}{c}\text { Role Play, Games, } \\
\text { Writing Dialogues and } \\
\text { Acting, Speaking Cards, } \\
\text { Pronunciation }\end{array}$ \\
\hline My Environment & Teenwise & 20 saat & $\begin{array}{c}\text { Acting, Role Play, } \\
\text { Introducing } \\
\text { Neighbourhood, Games } \\
\text { (Blind Man Buff), } \\
\text { Pronunciation }\end{array}$ \\
\hline Movies & Teenwise & 15 saat & $\begin{array}{c}\text { Guessing Games, } \\
\text { Watching parts of } \\
\text { movies, Pronunciation }\end{array}$ \\
\hline
\end{tabular}


Tablo 8 (devam)

\begin{tabular}{lccc}
\hline Temalar & $\begin{array}{l}\text { Yararlanılan } \\
\text { Kaynaklar }\end{array}$ & $\begin{array}{c}\text { Yıllık Planda } \\
\text { Unitelere Ayrılan } \\
\text { Ders Saatleri }\end{array}$ & $\begin{array}{c}\text { Calışmalar/Kullanılan } \\
\text { Ögretim Yöntem ve } \\
\text { Teknikleri, Materyaller }\end{array}$ \\
\hline Human in Nature & Teenwise & 15 saat & $\begin{array}{c}\text { Internet Websites, } \\
\text { Worksheets, Games, } \\
\text { Visuals, Pronunciation }\end{array}$ \\
\hline Celebrities & Teenwise & 20 saat & $\begin{array}{c}\text { Game (Guess who?), } \\
\text { Videos, Songs, } \\
\text { Pronunciation }\end{array}$ \\
\hline
\end{tabular}

Tablo 8 incelendiğinde, programa uyma ölçütünde öğretmenin programdaki etkinlik ve yöntemleri tercih ettiği, miktar ölçütünde öğretmenin programda sunulan temaları programda önerilen sürede tamamladığı, uygulamanın niteliği ölçütünde öğretmenin programa uygun ölçme ve değerlendirme yöntemleriyle (kısa sınavlar, uygulama sınavları, yazılı sınavlar) öğrenci başarısını dönem boyunca ölçtüğü ve programın etkililiğini belirlediği, katılımcıların tepkileri ölçüt olarak temel alındığında öğrencilere yönelik geliştirilmiş veri toplama araçlarından (öğrenci beklenti anketi, ara değerlendirme formu, son değerlendirme anketi) elde edilen bulgular doğrultusunda programda sunulan etkinliklere etkin katılım gösterdikleri ve programdan beklentilerinin sorulduğu görülmüştür.

Öğretmen dönem başında yenilenen programı inceleyerek öğretimini planlamış ve dönem boyunca uygulamalarına ilişkin ikinci araştırmacı ile görüşmeler yürütmüş ve dönem içerisinde notlar tutmuştur. Öğretmen notları incelendiğinde, ders öğretmeninin öğretim programında sunulan temalara yıllık planlarda belirtilen süreler dâhilinde, öğretim programının sunumunda kullandığı kaynaklardan, içerik sunumunda kullanılan öğretim etkinliklerinden söz ettiği görülmüştür. Buradan hareketle, öğretmenin "Studying Abroad" başlıklı temanın sunumunda "Teenwise" kitabını 20 saatlik ders süresinde "Role Play, Games, Writing Dialogues and Acting, Speaking Cards, Pronunciation" gibi materyal ve etkinliklerle desteklediği görülmüştür. "My Environment" temasında öğretmenin, "Teenwise" kitabını 20 saatlik bir çalışma ile "Acting, Role Play, Introducing Neighbourhood, Games(Blind man Buffs), Pronunciation" gibi etkinliklerle destekleyerek tamamladığı görülmüştür. Öğretmen notları incelendiğinde, Movies ünitesinde öğretmenin "Teenwise" adlı kaynak kitabı kullanarak 15 saatlik bir çalışma ile "Guessing game, watching parts of movies, Pronunciation" gibi etkinliklerle üniteyi tamamladığ 1 görülmüştür. Human in Nature temasında ise aynı kaynak kitap kullanılarak 15 saatlik bir çalışma ile "Internet Websites, Worksheets, games, visuals, pronunciation" gibi materyal ve etkinlikler kullanılarak tamamlandığı görülmüştür. Birinci dönemin son teması "Celebrities"de ise kaynak kitap kullanılarak 20 saatlik bir çalışma ile "Game (Guess who), videos, songs, pronunciation" gibi etkinlik ve materyallerle yürütülmüştür. Tablo 9'da öğretim programına bağlı yürütülen İngilizce dersinde öğrencilerin kendilerini rahat hissettikleri dil yeterliklerine yönelik bilgiler sunulmuştur. 
Tablo 9

Öğrencilerin Kendilerini Rahat Hissettikleri Dil Yeterlikleri

\begin{tabular}{lcc}
\hline Dil Yeterlikleri & f & \% \\
\hline Dinleme & 20 & 27 \\
Konuşma & 11 & 15 \\
Okuma & 7 & 9 \\
Yazma & 3 & 4 \\
Konuşma ve dinleme & 10 & 14 \\
Konuşma ve okuma & 4 & 5 \\
Dinleme ve yazma & 4 & 5 \\
Konuşma ve yazma & 3 & 4 \\
Konuşma, dinleme ve okuma & 5 & 7 \\
Konuşma, dinleme ve yazma & 2 & 3 \\
Dinleme, okuma ve yazma & 2 & 3 \\
Konuşma, dinleme, okuma ve yazma & 3 & 4 \\
\hline
\end{tabular}

Tablo 9'da öğretmenin programa bağlı olarak yürüttüğü İngilizce derslerinde, öğrencilerin kendilerini dönem boyunca daha rahat hissettikleri dil yeterlikleri incelenmiştir. Burada öğrencilere "Ingilizce dersinde aşă̆ldaki yeterliklerden hangilerinde kendinizi daha rahat hissediyorsunuz?" sorusu yöneltilmiş ve 65 öğrenciden alınan yanıtlar sunulmuştur. Bu yanıtlar incelendiğinde, öğrencilerin 20'si dinleme, 11'i konuşma, yedisi okuma, üçü yazma becerilerinde, 10'u konuşma ve dinleme, dördü konuşma ve okuma, dördü dinleme ve yazma, üçü konuşma ve yazma, beşi konuşma, dinleme ve okuma, ikisi konuşma, dinleme ve yazma, ikisi dinleme, okuma ve yazma, üçü konuşma, dinleme, okuma ve yazma becerilerinde kendilerini daha rahat hissettiklerini belirtmiştir. Buradan hareketle, öğrencilerin çoğunluğu $(\mathrm{f}=20)$ kendilerini dinleme ve konuşma $(\mathrm{f}=11)$ becerilerinde daha rahat ve yeterli hissetmektedir. Öğrencilerin önceki dönemlerdeki İngilizce dersleri ile mevcut dönemdeki İngilizce dersleri arasındaki farklılıklar Tablo 10’da sunulmuştur.

Tablo 10

Öğrencilerin Geçmiş Dönemlerdeki Ingilizce Dersleri ve Mevcut Dönemdeki Ingilizce Dersi Arasındaki Benzerlik / Farklılıklara Yönelik Analizleri

\begin{tabular}{lcc}
\hline Öğrenci Yanıtları & f & \% \\
\hline Derslerin uygulamalı olması & 22 & 34 \\
Derslerin daha eğlenceli ve verimli olması & 17 & 26 \\
Farklılığın olmaması & 7 & 11 \\
Derslerin İngilizce konuşmaya yönelik olması & 6 & 9 \\
Diğer dönemlerde derslerin daha eğlenceli ve verimli olması & 6 & 9 \\
Teknolojik materyallerin kullanılması & 4 & 6 \\
Daha fazla sözcük ezberi yapılması & 3 & 5 \\
\hline
\end{tabular}


Tablo 10'da öğretmenin programa bağlı olarak yürüttüğü İngilizce derslerinde öğrencilerin "Bu dönem katıldığın İngilizce dersleri geçmiş dönemlerde katıldığın İngilizce derslerinden nasıl farklılaşmaktadır? Açıklar mısın?" sorusuna vermiş oldukları yanıtları sunulmuştur. Dağılımlar incelendiğinde, 65 öğrencinin 22'sinin derslerin bu dönem uygulamalı (oyun çeşitliliği, etkinlikler, dinleme ve konuşma sinavları) olmast, 17'sinin bu dönem derslerin daha ĕglenceli ve verimli olması, yedisinin bu dönemki derslerin diğer dönemlerdeki derslerle aynı olması ve farklılı olmaması, altısının diğer dönemlerde derslerin daha ĕglenceli ve verimli olması, altısının bu dönem derslerin İngilizce konuşma ă̆ırlıkl olmass, dördünün diğer dönemlerde derste akıllı tahta, video vb teknolojik materyallerin kullanılması, üçünün diğer dönemlerde daha fazla sözcük ezberi yapılması gibi yanıtlar verdikleri görülmüştür. Bu verilere göre, bu dönem derslerin uygulamalı olması ve bu dönem derslerin daha eğlenceli ve verimli olması görüşleriyle katılımcı öğrenciler, İngilizce derslerinin diğer dönemlerde ele alınan derslere göre farklılaştığını açıklamışlardır. Bulgulara yönelik alıntılar aşağıda sunulmaktadır:

“Gelişme var artık uygulamalı olarak öğreniyoruz.” (Ö19)

“Önceki senelerde öğretmenlerimiz hiç uygulama yapmıyorlardı şimdi uygulamalı olarak daha çok öğreniyorum hem eğlenceli hem de akılda kalıcı oluyor." (Ö25)

"Daha eğlenceli ve daha anlaşılır çünkü canlandırma, ses dinleme, uygulama daha fazla anlamamızı sağlıyor.” (Ö57)

"Etkinlikler daha çok bu da dersin daha eğlenceli geçmesini sağlıyor." (Ö64)

"Diğer dönemlere göre İngilizce dersimin daha iyi olduğunu düşünüyorum bunun sebebi yapılan etkinliklerin, alıştırmaların etkili oluşu.” (Ö65)

Tablo 11

Öğrencilerin Dönem Sonunda Kazandıklarını Düşündükleri Ingilizce Dil Yeterlikleri

\begin{tabular}{lcc}
\hline Yeterlikler & f & \% \\
\hline Konuşma & 23 & 31 \\
Dinleme & 13 & 17 \\
Yazma & 4 & 5 \\
Okuma & 2 & 3 \\
Konuşma ve dinleme & 12 & 16 \\
Okuma ve yazma & 4 & 5 \\
Konuşma ve okuma & 3 & 4 \\
Konuşma ve yazma & 2 & 3 \\
Okuma ve dinleme & 2 & 3 \\
Konuşma, dinleme ve okuma & 5 & 7 \\
Konuşma, okuma ve yazma & 1 & 1 \\
Konuşma, dinleme ve yazma & 1 & 1 \\
Dinleme, okuma ve yazma & 1 & 1 \\
Konuşma, dinleme, okuma ve yazma & 2 & 3 \\
\hline
\end{tabular}


Tablo 11'de öğretmenin programa bağl1 olarak yürüttüğg̈ İngilizce derslerinde öğrencilerin "Dönem sonunda İngilizce dersinde hangi yeterlikleri kazandiğınızı düşünüyorsunuz? Neden açıklar mısınız?"sorusuna ilişkin verdikleri yanıtlar incelenmiş ve yanttlara yönelik betimsel analiz sunulmuştur. Yanıtlar incelendiğinde, dönem sonunda 65 öğrenciden 23'ünün konuşma, 13'ünün dinleme, dördünün yazma, ikisinin okuma, 12'sinin konuşma ve dinleme, dördünün okuma ve yazma, üçünün konuşma ve okuma, ikisinin konuşma ve yazma, ikisinin okuma ve dinleme, beşinin konuşma, dinleme ve okuma, birinin konuşma, okuma ve yazma, birinin konuşma, dinleme ve yazma, birinin dinleme, okuma ve yazma, ikisinin konuşma, dinleme, okuma ve yazma gibi becerileri kazandıklarını düşündükleri görülmektedir. $\mathrm{Bu}$ bilgilere göre öğrencilerin çoğunluğunun ( $\mathrm{f}=23)$ konuşma, $(\mathrm{f}=13)$ dinleme becerilerini kazandıkları söylenebilir. Bu görüşleri destekler nitelikte alıntılar şöyle sıralanabilir:

"Hocamız İngilizce konuştuğu için konuşma becerimiz ve dinleme becerimiz gelişiyor." (Ö21)

"Dönem sonunda İngilizcede dinleme ve konuşma yeterliliği kazandım çünkü hocamız bunlara yönelik çok fazla sınav yaptı." (Ö25)

"Konuşma çünkü kendimi daha iyi ifade edebiliyorum.” (Ö36)

"Dinleme yeterliliği kazandım. Dinlediklerimi daha kolay anlıyor, daha kolay yorumluyorum." (Ö44)

"Konuşma, çünkü hocamız İngilizce konuştuğunda artık daha rahat anlıyoruz ve hocamızın konuşmasını ilgi çekici buluyorum.” (Ö45)

Tablo 12

Öğrencilerin Dönem Boyunca İngilizce Öğrenmelerini Kolaylaşttran Etkinlikler

\begin{tabular}{lcc}
\hline Etkinlikler & f & \% \\
\hline Dinleme etkinlikleri & 17 & 26 \\
Oyun & 15 & 23 \\
Kısa sınavlar & 13 & 20 \\
Konuşma etkinlikleri (diyalog, canlandırma) & 12 & 18 \\
Sözcük çalışmaları & 6 & 9 \\
İngilizce çeviri & 1 & 2 \\
Grup çalışmaları & 1 & 2 \\
\hline
\end{tabular}

Tablo 12'de öğretmenin programa bağlı olarak yürüttüğü İngilizce derslerinde öğrencilere "Dönem boyunca ögrrenmenizi kolaylaştıran etkinlikler nelerdi? Neden?" sorusu yöneltilmiş ve alınan yanıtlar sunulmuştur. Yanıtlar incelendiğinde, 65 öğrencinin 17'si dinleme etkinlikleri, 15'si oyun, 13'ü klsa sinavlar, 12'si konuşma etkinlikleri, altısı sözcük çalışmaları, biri İngilizce çeviri, biri grup çalışmaları gibi etkinliklerin İngilizce öğrenmelerini kolaylaştırdığını belirtmiştir. Bu bilgilere göre 
öğrencilerin İngilizce öğrenmelerini kolaylaştıran etkinliklerin başında dinleme etkinlikleri $(\mathrm{f}=17)$ ve oyun $(\mathrm{f}=15)$ gelmektedir.

$\mathrm{Bu}$ değerlendirme anketinin beşinci sorusunda öğretmenin programa bağlı olarak yürüttüğü İngilizce derslerinde öğrencilere "Ders beklentilerinizi karşıladı $m \imath$ ?" "sorusu sorulmuş ve verdikleri yanıtlar incelenmiştir. Bu soruyu öğrencilerin 58 'inin "evet", yedisinin "hayır" olarak yanıtladıkları görülmüştür. Bu bilgilere göre, öğrencilerin çoğunluğunun ( $\mathrm{f}=58)$ "evet" olarak yanttlaması, dersin beklentilerini karşıladığını göstermiştir.

Tablo 13

Öğrencilerin Ingilizce Dersine Yönelik En Çok Hoşlarına Giden Uygulamalar

\begin{tabular}{lcc}
\hline Ders İçi Uygulamalar & f & \% \\
\hline Oyun ve etkinlik & 23 & 35 \\
Öğretmenin özverisi & 12 & 19 \\
Ders akışının İngilizce sürmesi & 10 & 16 \\
İngilizce şarkı dinleme & 8 & 12 \\
Sözcük çalışmaları & 6 & 9 \\
Kısa sınavlar & 4 & 6 \\
İngilizce-Türkçe çeviri & 2 & 3 \\
\hline
\end{tabular}

Tablo 13'te öğretmenin programa bağlı olarak yürüttüğg̈ İngilizce derslerinde öğrencilere "Ders ile ilgili en çok hoşlandiğınız uygulamalar nelerdi?" "sorusu yöneltilmiş ve yanıtları sunulmuştur. $\mathrm{Bu}$ veriler incelendiğinde, 65 öğrencinin 23'ünün oyun ve etkinlik, 12'sinin ögretmenin özverisi, 10'unun ders aklşının İngilizce sürmesi, sekizinin İngilizce şarkı dinleme, altısının sözcük çalışmaları, dördünün klsa sinavlar, ikisinin İngilizce-Türkçe çeviri olarak yanıtlandırdıkları görülmüştür. Tabloda sunulan bilgilere göre öğrencilerin İngilizce dersine yönelik en çok hoşlarına giden şeylerin oyun ve etkinlikler $(\mathrm{f}=23)$ ve öğretmenin özverisi $(\mathrm{f}=12)$ olduğu göze çarpmaktadır. Bulgular ile paralel yöndeki alıntılardan bir bölümü aşağıda sunulmaktadır:

"Hocamızın bize karşı gösterdiği anlayış ve tatlı dili.” (Ö14)

"Hocamızın mutlu ve eğlenceli bir şekilde ders anlatması, şarkı dinletmesi, oyun oynatması, elimizde pek kaynak olmasa da çok çaba sarf ediyor." (Ö25)

"Hocamızın İngilizce konuşması ve bizim anlamamızı sağlayacak şekilde işaret dili kullanması." (Ö28)

"Konuları oyunlar oynayarak akılda kalıcı olmasını sağlıyorsunuz. Bizim bazen sıkıldığımızı anlayınca küçük oyunlarla derse dönmemizi sağlıyorsunuz." (Ö37)

"Bol bol etkinlik yapmak, dersler eğlenceli geçiyor." (Ö45) 
Tablo 14

Öğrencilerin Ders ile İlgili Hoşlanmadıkları Durumlar ve Etkinlikler

\begin{tabular}{lcc}
\hline Öğrenci Sayıları & f & \% \\
\hline Yok & 38 & 58 \\
Dinleme etkinlikleri & 7 & 10 \\
Konuşma etkinlikleri (diyalog, canlandırma) & 6 & 9 \\
Ders gürültülü & 4 & 6 \\
Ders akışının İngilizce oluşu & 4 & 6 \\
Ders sıııı & 2 & 3 \\
İngilizce metin çeviri & 1 & 2 \\
Yazma etkinlikleri & 1 & 2 \\
Dersin test çözmeye yönelik olmayışı & 1 & 2 \\
Ders kitaplarının eksikliği & 1 & 2 \\
\hline
\end{tabular}

Tablo 14'te ise öğretmenin programa bağl1 olarak yürüttüğü İngilizce derslerinde öğrencilerin "Ders ile ilgili hoşlanmadı̆̆ınız durumlar ve etkinlikler nelerdir?" sorusuna yönelik verdikleri yanıtları sunulmuştur. Sıklıklar incelendiğinde, 65 öğrenciden 38'i yok, yedisi dinleme etkinlikleri, altısı konuşma etkinlikleri (diyalog, canlandırma), dördüü ders gürültülü, dördü ders akışının İngilizce oluşu, ikisi ders sıkıcı, biri Ingilizce metin çeviri, biri yazma etkinlikleri, biri dersin test çözmeye yönelik olmayışı, biri ders kitaplarının eksikliği biçiminde yanıtlamıştır. Tabloda sunulan bilgilere göre öğrencilerin çoğunluğu (f=58) İngilizce dersinde hoşlanmadıkları durum ve etkinliğin olmadığını belirtmiştir.

\section{3. Öğrencilerin dönem boyunca İngilizce dinleme, konuşma, okuma ve yazma becerilerine yönelik aldıkları sınav puanları}

Aşağıda, öğrencilerin dönem başı dinleme ve konuşma sınavları ile dönem ortası birinci ve ikinci yazılı sınavlar ve dönem sonu uygulama sınavına ilişkin bulgular sunulmuştur.

Tablo 15

Öğrencilere Dönem Boyunca Uygulanan Sinavların Puanları

\begin{tabular}{cccccc}
\hline & $\begin{array}{c}\text { Dönem Başı } \\
\text { Dinleme } \\
\text { Sınavı }\end{array}$ & $\begin{array}{c}\text { Dönem Başı } \\
\text { Konuşma } \\
\text { Sınavı }\end{array}$ & $\begin{array}{c}\text { Dönem } \\
\text { Ortası } \\
\text { 1.Yazılı } \\
\text { Sınav }\end{array}$ & $\begin{array}{c}\text { Dönem } \\
\text { Ortası } \\
\text { 2.Yazılı } \\
\text { Sınav }\end{array}$ & $\begin{array}{c}\text { Dönem Sonu } \\
\text { Uygulama } \\
\text { Sınavı }\end{array}$ \\
\hline Ö1 & 48 & 35 & 73 & 91 & 82 \\
Ö2 & 48 & 38 & 92 & 91 & 91 \\
Ö3 & 36 & 25 & 57 & 69 & 65 \\
Ö4 & 24 & 30 & 63 & 76 & 61 \\
Ö5 & 20 & 30 & 70 & 71 & 72 \\
Ö6 & 12 & 30 & 49 & 80 & 84 \\
Ö7 & 36 & 32 & 62 & 82 & 71 \\
Ö8 & 8 & 35 & 60 & 68 & 73 \\
\hline
\end{tabular}

(devam ediyor) 
Tablo 15 (devam)

\begin{tabular}{cccccc}
\hline & $\begin{array}{c}\text { Dönem Başı } \\
\text { Dinleme } \\
\text { Sınavı }\end{array}$ & $\begin{array}{c}\text { Dönem Başı } \\
\text { Konuşma } \\
\text { Sınavı }\end{array}$ & $\begin{array}{c}\text { Dönem } \\
\text { Ortası } \\
\text { 1.Yazılı } \\
\text { Sınav }\end{array}$ & $\begin{array}{c}\text { Dönem } \\
\text { Ortası } \\
\text { 2.Yazılı } \\
\text { Sınav }\end{array}$ & $\begin{array}{c}\text { Dönem Sonu } \\
\text { Uygulama } \\
\text { Sınavı }\end{array}$ \\
\hline Ö9 & 28 & 30 & 57 & 58 & 79 \\
Ö10 & 20 & 30 & 82 & 92 & 85 \\
Ö11 & 8 & 30 & 69 & 86 & 66 \\
Ö12 & 8 & 22 & 47 & 71 & 70 \\
Ö13 & 56 & 20 & 77 & 66 & 74 \\
Ö14 & 20 & 15 & 68 & 69 & 73 \\
Ö15 & 60 & 38 & 82 & 98 & 95 \\
\hline
\end{tabular}

Tablo 15 'te 15 öğrencinin dönem başında uygulanan dinleme ve konuşma sınavlarına, dönem ortasında uygulanan 1 . ve 2 . yazılı sınava, dönem sonunda uygulanan uygulama sınavına ilişkin bulgular sunulmuştur. Sene başında yapılan dinleme sınavı, toplam 60 puandır, konuşma sınavı da 40 puan olmak üzere, iki sınav toplamda 100 puandan oluşmaktadır. Dönem başında uygulanan dinleme sınavının ortalaması, 60 üzerinden 25 'tir. Dönem başında yapılan dinleme sınavında, bir öğrenci (Ö15) tam puan almıştır. Dönem başında uygulanan konuşma sınavının ortalaması, 40 puan üzerinden 29'dur. Dönem başında uygulanan konuşma sınavında dinleme sınavına koşut olarak dinleme sınavında başarı gösterenler, konuşma sınavında da başarı göstermiştir (Ör. Ö1, Ö2, Ö7, Ö15 vb.). Birinci yazılı sınavın ortalaması, 100 üzerinden 66 'dır. İkinci yazılı sınavın ortalaması 100 üzerinden 76 'dır. Uygulama sinavının ortalaması ise 73 'tür. Dönem ortasında yapılan öğrencilerin birinci ve ikinci yazılı sınav puanları incelendiğinde, 15 öğrenci arasından 13 ögrencinin birinci yazılı sınava oranla ikinci yazılı sınav puanlarının arttı̆̆ı gözlenmiş̧ir.

Dönem boyunca uygulanan sınavlar değerlendirildiğinde, genel olarak 65 öğrencide, dönem başında uygulanan dinleme ve konuşma becerisi sınavlarında yüksek not alan öğrenciler ( $\mathrm{f}=23$ ), dönem sonunda uygulanan uygulama sınavında da yüksek not almışlardır. Dönem sonunda gerçekleştirilen uygulama sınavlarına bakıldığında, dönem başında yapılan dinleme ve konuşma sınavlarında başarı gösteren öğrencilerin, dönem sonundaki uygulama sınavında da başarı gösterdiği görülmüştür. (Ör. Ö1, Ö2, Ö13, Ö15.) Tablo 15 ’te sunulan on beş öğrenciden elde edilen bulgular doğrultusunda, sekiz öğrencinin uygulama sınav puanının yazılı sınavlarına oranla daha düşük olduğu görülmüştür. Genele bakıldığında ise, öğrenciler ( $\mathrm{f}=25)$, uygulama sınavından yüksek not alırken öğrencilerin $(\mathrm{f}=40)$, uygulama sınavından birinci ve ikinci yazılı sınava oranla daha düşük notlar aldıkları görülmüştür. Tüm bulgular değerlendirildiğinde, sene başında kendini dinleme becerisine yönelik etkinliklerde rahat hisseden kadın öğrencilerin ( $f=11$ ), dinleme ve uygulama sınavlarının dinleme bölümlerinden yüksek notlar aldıkları görülmüştür. (Ör.Ö2, Ö13, Ö15, Ö28,Ö35, Ö39,Ö40, Ö43,Ö45,Ö46, Ö51 gibi.) 


\section{Tartışma, Sonuç ve Öneriler}

$\mathrm{Bu}$ bölümde araştırmanın bulgularına yönelik tartışma ve önerilere yer verilmiştir. $\mathrm{Bu}$ çalışma, öğrencilerin yenilenen 9. sınıf İngilizce dersi öğretim programına yönelik beklentilerinin neler olduğu, öğretmenin programa bağlı uygulama yaptığı durumda, dönem sonunda bu beklentilerin ne kadarının karşılandığı ve öğrencilerin farklı dil becerilerine yönelik ders başarılarının araştırıldığı bir durum çalışmasıdır. Dönem boyunca öğretmen, öğretim programında belirtilen temaları, sunulan kaynak kitap eşliğinde, yıllık planda belirtilen sürelere sadık kalarak ve öğretim programında önerilen etkinlik ve materyal çeşitliliği sağlayarak tamamlamıştır.

Araştırma bulguları, programa bağlılığı ölçmeye yönelik Dane ve Schneider (1998), Dusenbury ve diğ, (2003) ve O’Donnell (2008) tarafindan bağlilı̆̆ belirlemede kullanılan beş ölçüte (uyma, miktar, uygulamanın / dağıtımın niteliği, katılımcıların tepkileri, ve program farklılıkları) göre değerlendirildiğinde: Programa uyma basamağında, öğretmen notlarına göre öğretim programında belirtilen etkinlik ve yöntemlerin uygulandığı; miktar basamağında, katılımcılara sunulan öğretim programında belirtilen beş program içeriğinin/temanın öğretme-öğrenme sürecinde programda önerilen sürelere uyularak sunulduğu, dönem boyunca oturum sayılarına, öğrenci katılımına dikkat edildiği görülmüştür. Uygulamanın kalitesi basamağında ise, öğretmenin uyguladığı sınavlar ve bunlardan elde edilen puanların yüksek olması ile programın etkililik oranının yüksek olduğu; katılımcıların tepkileri basamağında ise öğrencilerin etkin katılımcı olarak öğretme-öğrenme sürecine ve etkinliklere katılması ve dört dil becerisinden özellikle dinleme ve konuşma etkinliklerinde etkin olmaları; program farklılıkları basamağında ise mevcut programda önceki programdan farklı olarak, dinleme ve konuşma etkinliklerine ağırlık verildiği, öğrencilerin İngilizce iletişim kuran, etkin katılımcı rolü üstlendikleri görülmüştür. Ölçme-değerlendirmede ise yazılı sınavlar, uygulama sınavları, tartışma zamanı gibi etkinlikler yoluyla programda belirtildiği gibi hem geleneksel hem de alternatif yöntemler ve elektronik ölçme-değerlendirme yöntemleri ile öğretimin değerlendirilmesine yer verildiği görülmüştür. Araştırma süresinde kullanılan veri toplama araçlarından elde edilen bulgular göstermiştir ki, öğretmenin öğretim programında sunulan yenilik ve reformlara kısacası öğretim programına genel itibarıyla bağlı kalması, öğrencilerin hedeflendiği gibi İngilizce dersinin etkin birer uygulayıcısı olmalarına önemli katkı sağladığı sonucuna ulaşılmıştır.

Okulun fiziki alt yapısı düşünüldüğünde, okulda akıllı tahta vb gibi teknolojik alt yapının olmayışı, teknolojik materyal çeşitliliğini ve ulaşımı sınırlandırmıştır. Teknolojik materyal çeşitliliğinin sınırlı oluşu da ders içerisinde kullanılan görsel, işitsel, hem görsel hem de işitsel zekaya hitap eden materyallerin sınıf içerisinde sunumunu ve ulaşımını kısıtlı tutmaktadır. Ayrıca, öğrencilere yeni bakış açıları sunabilecek teknolojik materyal ve etkinliklerin kullanılma kısıtlılı̆̆ı, öğrencilerin yabancı dil öğrenmede sınıf içerisinde ulaşabilecekleri teknolojik materyali ve İngilizceyi kullanma alanını sınırlı tutmaktadır denilebilir. Buradan hareketle, öğretim programlarını hazırlama aşamasında, okulların fiziki koşullarının göz önünde 
bulundurulmaması, materyal çeşitliliğini, öğretimde kullanılan teknolojik uygulama çeşitliliğini sınırlandırmakta olduğu söylenebilir. Benzer şekilde, Coşkun-Demirpolat (2015), yabancı dil sınıflarında, dinleme ve izleme etkinliklerini yürütebilmek için teknolojik alt yapının sağlanması gerektiğini belirtir. Hazarika (2017), teknolojinin İngilizce öğretimine etkisine yönelik yürütmüş olduğu çalışmasında teknolojinin, İngilizce öğretiminde, daha yaratıcı, yenilikçi, üretici ve ilgi çekici seçenekler sunduğunu belirtilmiştir.

Dönem başında öğrencilerin öğretim programından beklentilerine ilişkin bulgular incelendiğinde, öğrencilerin yenilenen ortaöğretim 9. sınıf İngilizce dersi öğretim programında daha çok dinleme ve konuşma becerilerine ilişkin öğretim etkinliklerinin olmasını istedikleri, konuşma ve dinleme becerilerini kazanmayı hedefledikleri görülmüsstür. Dönem sonunda elde edilen bulgular da bunu destekler niteliktedir. Dil öğrenmenin doğası gereği dinleme ve konuşma becerilerinin öncü dil yeterliliği olması bunun bir sonucu olabilir. Ayrıca öğrencilerin öğrendikleri dilin işlevsel olmasını sağlayan alanlardan birinin konuşma becerisi olduğu söylenebilir. Öğrenciler, öğrendikleri dili etkin bir şekilde kullanarak ve dinlediğini anlayarak üretken hale gelebilir. Bu üretkenlik ve iletişim kurabiliyor olma yetisi, öğrencilerin bu becerilere daha fazla ağırlık verme nedenidir denilebilir. Benzer şekilde, yenilenen ortaöğretim 9. sınıf İngilizce dersi öğretim programında da dil becerilerini kazandırmada dinleme ve konuşma becerilerini kazandırma, iletişimsel yaklaşımın bir gerekliliği olarak görülmektedir (MEB, 2017). Seraj ve Maun (2011) konuşma ve dinleme becerilerinin, hedef dilde iletişim kurmada en önemli iki beceri olduğunu, iletişimsel yaklaşımın ise yabancı dil öğretiminde dört dil becerisine de eşit derecede vurgu yaptığını belirtmiştir.

Okuma ve yazma becerilerine kıyasla, öğrencilerin dinleme ve konuşma becerilerine yönelmeleri, öğrencilerin yabancı dilde etkin iletişim kurma istekleri ile açıklanabilir. Öğrencilerin beklentilerine ilişkin diğer bir bulguya göre ise, çevrimiçi materyal kullanımı (video, oyun, slayt, akıllı tahta) ve tartışma zamanı gibi etkinlikler derste öğrencilerin çoğunlukla tercih ettikleri uygulamalardır. Yazıll, görsel ve işitsel ögeler içeren çevrimiçi materyallerin öğretim etkinliklerini çeşitlendirmede, öğrenmeyi desteklemekte önemli bir etkisinin bulunduğu sonucuna ulaş1labilir. Dağhan, Kibar, Akkoyunlu ve Atanur (2015) tarafından gerçekleştirilen çalışmada eiçerik/çevrimiçi materyal kullanımının öğrenmeyi kolaylaştırdığı belirtilmiştir. Benzer şekilde 2017 yllında yenilenen öğretim programında da konuşma ve dinleme becerilerini ölçmeye yarayan çevrimiçi materyal ve tartışma zamanı gibi içerikler önerilmiştir (MEB, 2017).

Öğrencilerin yenilenen öğretim programından ve ders işlenişine ilişkin düzenlemelere yönelik diğer bir beklentileri ise derste canlandırma, eğitsel oyun gibi etkinliklerin kullanımının arttırılmasıdır. Öğrencilere göre, canlandırma ve eğitsel oyunlar gibi teknikler ile ders, daha eğlenceli ve etkili hale gelmektedir. Liu ve Ding (2009) canlandırma etkinlikleri üzerine yaptıkları çalışmanın sonucunda İngilizce öğretiminde başarı için önemli etkenlerden birinin de canlandırma etkinlikleri 
olduğunu ve bu etkinliklerin sınıf içerisinde dersle bütünleştirilmesinin çeşitlilik sağlayacağını, dilde üretim olanağı tanıyacağını ve dersi eğlenceli hale getireceğini belirtmişlerdir. Benzer bir görüşle, Bouaziz (2015) anlandırma tekniği yoluyla konuşma becerisinin geliştirilmesini hedeflemiş olup bu tekniğin gerçek yaşam durumlarını sınıf ortamına getirmesi, öğrencilerin farklı sosyal durumlarda etkili bir şekilde iletişim kurabilmelerini sağlaması gibi bireylerin kendilerini daha iyi ifade etmelerini sağlayan ortamlar oluş̧urduğunu dile getirmiştir. Benzer şekilde, Bosan (2013) ve Kuśnierek de (2015) canlandırma etkinliklerinin öğrencileri konuşmaya güdüleyerek, konuşma becerilerini desteklemede ve etkileşim sağlamada önemli etkilerinin olduğunu, canlandırma tekniğinin yanı sıra, yabancı dil ediniminde ders içerisinde tartışma, karşılıklı konuşma oluşturma gibi farklı etkinliklerin kullanımının, konuşma becerisini de olumlu yönde etkileyip dil gelişimine katkı sunacağını belirtmişlerdir. Araştırma kapsamında gerçekleştirilen doküman analizine göre, yenilenen ortaöğretim 9. sınıf İngilizce dersi öğretim programında da canlandırma ve oyun etkinliklerinin önerilen etkinlikler arasında yer aldığı görülmüştür (MEB, 2017).

Öğrencilerin İngilizce dersine yönelik diğer bir beklentilerinde ise ders içi diyalogların arttırılması yönünde bir eğilim göze çarpmaktadır. Bir başka deyişle, öğrenciler uygulamaya dönük etkinliklere önem vermektedir. Buna yönelik kullanılan drama yöntemi, yabancı dili bağlam içerisinde ele alma firsatı sağladığı için, öğretimin daha gerçekçi koşullar içinde gerçekleşmesini sağlamaktadır. Albalawi (2014) drama yöntemini kullanarak İngilizce öğretiminde yaratıcı düşünme becerisini geliştirmeye yönelik yaptığı çalışmada dramanın, yaratıcı düşünmeyi geliştirdiğini bulgularıyla desteklemiştir. Diğer bir çalışmada Křivková, (2011) dramanın öğrencilerin hem içsel hem de dışsal güdülenmesini arttırdığını, anlamı bağlam içerisinde sunduğunu ve öğrencilerin gerçek yaşam durumları ile karşılaşmalarını sağladığını ayrıca farklı ögrenme yollarına ve çoklu zekaya seslendiğini, gerçek yaşamla karşı karşıya getirdiği için öğrencilerin içinde bulunduğu psikolojik durumları da daha iyi anlamalarını sağladığını belirtmiştir. Öğrenci merkezli bir öğrenme yöntemi olarak drama da, öğrencilere yaparak yaşayarak öğrenme firsatları sunmaktadır.

Derste eğitsel oyunların kullanımı, İngilizce derslerinde öğrenciler arasında en çok tercih edilen ikinci öğretim tekniği olarak göze çarpmaktadır. Öğrencilerin öğretim programına ve İngilizce dersine yönelik beklentilerinden biri ise dersin oyunlar aracillğıyla yürütülmesidir. Buradan hareketle öğrencilerin eğlenerek öğrenmeyi sevdikleri, eğlendiklerinde daha kalıcı ve etkili öğrendikleri düşünülebilir. Dil öğretiminde oyunların kullanımı üzerine yapılan çalışmalar, mevcut çalışma ile benzer bulgular içermektedir. Örneğin, Pasovic-Petrovic'in (2014) yapmış olduğu çalışma sonuçları göstermektedir ki, öğrenciler, oyun oynarken yeni öğrendikleri dile karşı daha meraklı ve istekli bir tutum geliştirmektedirler; ancak öğrenen bireylerin oyunlardan etkili bir şekilde yararlanabilmeleri için oyunların bilinçli bir şekilde kullanılması gerekir. Alpar (2013) yapmış olduğu çalışmasında, oyunların konuşma, dinleme, okuma ve yazma gibi dil becerilerine ve ders başarısına katkısından söz etmiştir. 
Ara değerlendirme formundan elde edilen bulgular doğrultusunda, öğrencilerin İngilizce dersinden memnun olduklarını belirttikleri görülmüştür. Buradan hareketle, öğrencilerin İngilizce dersine ilişkin beklentilerinin karşılandığı söylenebilir. Benzer şekilde, ulusal alan yazında aynı öğretim programına ilişkin yapılan çalışmalardan, 2017 yılında yenilenen ortaöğretim İngilizce dersi öğretim programına yönelik gerçekleştirilen program değerlendirme çalışmasında, etkinliklerin öğrencilerin dil düzeylerine ve yaşlarına uygun olduğu, programın iletişimsel yaklaşıma ve öğrenci düzeyine uygun olduğu, hedef dilin kültürel etkinliklerine yer verildiğine değinilmiştir (Yüce, 2018).

Dönem ortasında uygulanan ara değerlendirme formuna ilişkin bulgularda öğrencilerin, İngilizce dersinde herhangi bir değişiklik yapılmaması gerektiğine yönelik düşünceleri, onların İngilizce dersine ve öğretim programına ilişkin beklentilerinin karşılandığını göstermektedir.

Araştırmadan ortaya çıkan diğer bir önemli sonuç ise, öğrencilerin İngilizce dersinde Türkçe kullanılmaması ve derslerin İngilizce dilinde yürütülmesi yönündeki beklentileri olmuştur. Bu doğrultuda, öğrencilerin yaşantılarında İngiliz diline maruz kaldıkları tek ortamın sınıf ortamı olduğu düşünüldüğünde, etkili dil edinimi için yabancı dil sınıflarında, ilgili yabancı dilin kullanılmasının bir ihtiyaçtan öte bir gereklilik olduğu düşünülmektedir. Ortaöğretim 9. sınıf İngilizce dersi öğretim programında da bu bulguyu destekler nitelikte "Students communicate in English in the classroom at all times." "(Öğrenciler sınıf içerisinde her zaman İngilizce iletişim kurar.)" ve "Teachers communicate in English in the classroom at all times." "(Öğretmenler sınıf içerisinde daima İngilizce iletişim kurar.)" ifadeleri İngilizce öğrenme ve öğretme çevresi olarak sunulmuştur (MEB, 2017, s.10). Paker (2012) yabancı dil öğretiminde öğretmenin görev ve sorumluluklarını tanımlarken ögretmenin hedef dili kullanmada ve sunmada bir anne gibi cömert ve sabırlı olması gerektiğini, dil öğretiminin başından devam eden süreç boyunca girdi sağlamaya ve bu girdinin de hedef dille olması gerektiğine dikkat çekmiştir. Özer ve Korkmaz (2016) ise dersin anlaşılmadığı halde sadece İngilizce işlenmesinin öğrenci başarısını olumsuz etkilediğini belirtmiştir.

Öğrencilere dönem başından sonuna kadar uygulanan bütün yazılı ve uygulama sınavlarından elde edilen bulgular doğrultusunda, dönem başında konuşma ve dinleme sınavlarında başarı gösteren, İngilizce dersinde de özellikle konuşma ve dinleme becerisine yönelik etkinliklerin arttırılması gerektiğini belirten öğrencilerin, dönem sonunda yapılan uygulama sınavının dinleme ve konuşma basamağında da başarı gösterdikleri sonucuna ulaşılmıştır. Buradan hareketle, dinleme ve konuşma etkinliklerinin dönem boyunca istikrarlı biçimde yürütüldüğü sonucuna ulaşılabilir.

Öğrencilerin dönem sonunda kazanmayı düşündükleri dil becerilerine bakıldığında ise, konuşma ve dinleme becerisinin, yenilenen ortaöğretim 9. sınıf İngilizce dersi öğretim programında da olduğu gibi birinci sırada yer aldığı sonucuna ulaşılmıştır. 
Dönem sonunda uygulanan sınavlardan hareketle, öğrencilerin kendilerini rahat hissettikleri dil becerileri arasında öncelikli sırayı dinleme sonra konuşma becerisi almaktadır. Dinleme becerisinin öğrencilerin rahat hissettiği bir beceri olmasının nedeni öğrencinin üründen çok süreç içerisindeki gelişimine katkı sunması ve öğrenciden anlık bir ürün oluşturmasının istenmeyişi olabilir.

Dönem sonunda uygulanan dört dil becerisini ölçmeye yönelik uygulama sınavından elde edilen bulgular doğrultusunda, öğrencilerin dönem sonunda uygulanan uygulama sınavı notlarının, dönem ortasında uygulanan iki yazılı sınav notlarına göre daha düşük olduğu görülmüştür. Bunun ise öğrencilerin, önceki dönemlerde dört dil becerisini ölçmeye yönelik herhangi bir değerlendirilmeye tabi tutulmamalarının bir sonucu olabileceği düşünülmektedir. Bu durum, öğrencilerin her dil becerisine yönelik ayrı bir sınav uygulaması ile daha önce karşılaşmadıkları için bu ilk uygulamada düşük notlar almaları, yazılı sınav sistemine alışkın oldukları için ise yazılı sınavlarda daha yüksek not almaları şeklinde açıklanabilir.

"Dokuzuncu sınıf İngilizce dersi öğretim programı Avrupa Dilleri Öğretimi Ortak Çerçeve Programında (ADOÇP) açıklanan A1 ve A2 düzeylerine denk gelmektedir." A1 düzeyinde öğrencinin, "somut ihtiyaçlarını karşılayabilmek için basit günlük ifadeleri kullanması ve anlaması, başkalarına kendini tanıtabilmesi, nerede yaşadığına, nelere sahip olduğuna dair kişisel bilgiler vermesi, basit düzeyde iletişim kurması" beklenmektedir (MEB, 2018, s. 22). A1 düzeyi yeterlikleri değerlendirildiğinde, öğrencilerin konuşma ve uygulama sınav sonuçları ve öğretmenin programa bağlılığı değerlendirildiğinde, bu yeterliklerin kazandırıldığı sonucuna varılmaktadır. Ögrencilerin dönem sonunda, A1 düzeyinde kazanımlara ulaştıkları, dört dil becerisinde istenilen düzeye geldikleri söylenebilir.

Dönem sonunda öğrencilerin, 2017 yılında yenilenen ortaöğretim 9. sınıf İngilizce dersi öğretim programına yönelik beklentilerinin karşılanıpkarşılanmadığına ilişkin bulgular incelendiğinde, dinleme ve konuşma becerilerinde yeterlik kazandıkları düşüncesi, dersin bu dönem daha çok uygulamaya dönük oluşu, dersin oyun ve etkinliklerle yürütülüşü ve derse ilişkin hoşlanmadıkları herhangi bir durumun söz konusu olmayışı, öğrencilerin yenilenen ortaöğretim 9. sınıf İngilizce dersi öğretim programına ve programa bağlı kalınarak uygulamaların yürütüldüğü İngilizce derslerine ilişkin beklentilerinin karşılandığı sonucunu göstermektedir. Songer ve Gotwals (2005), programa bağl1lık kavramı üzerine öğrencilerle yürütülen araştırmalarda, yüksek bağl1lığın benimsendiği öğrenci gruplarında, düşük bağlllığın benimsendiği gruplara göre daha yüksek puanlar alındığını ve hedef-davranışların daha fazla kazanıldığını vurgulamışlardır. Ayrıca programa bağlı kalınarak yürütülen İngilizce derslerinin, öğrencilerin ders başarısını da arttırdığı söylenebilir. Ancak Bümen, Çakar ve Yıldız (2014), Türkiye'de öğretim programına bağlılığa ilişkin yürütmüş oldukları çalışmada, Türkiye'de öğretim programı reformlarının öğretmenler tarafindan yeterince takip edilmediğine ve öğretim programına yeterince bağlı kalınmadığı sonucuna ulaşmışlardır. Benzer şekilde, Wiles ve Bondi (2007), öğretim programlarının \%90'ının uygulanmada başarısız olduğunu, eğitimcilerin, 
yeni bir öğretim programını uygulamak için gereken bilgi ve yönetsel becerilerden yoksun olduklarını belirtmişlerdir.

Programa bağlılık ilkesi doğrultusunda ise öğrencilerin, dinleme ve konuşma gibi iletișimsel becerilerine yönelik etkinliklere ağırlık verilmesi, sınıf içerisinde ağırlıklı olarak İngilizcenin kullanılması, oyun ve etkinliklerin sınıf içi uygulamalarda başlıca etkinlik olarak sunulması gibi beklentilerinin programla örtüştügü görülmüştür (MEB, 2017).

Öğrencilerin dönem başında belirttikleri beklentilerinin dönem sonunda karşılanması ve öğrencilere sunulan sınavların sonucunda dönem için belirlenen hedef-davranışları kazanmış olmaları, öğretmenin öğretim programında belirtilen etkinlikleri uygulamaya karşı istikrarı, dönem sonunda öğrencilerin İngilizce dersine karşı memnuniyetini ve İngilizce dersinde belirlenen hedef-davranışları kazanmalarını sağlamıştır.

\section{Öneriler}

Araştırma bulgularına dayalı olarak, öğretmenlere, öğrencilere, MEB ve okullara yönelik aşağıdaki öneriler sunulabilir:

Öğretmenlere yönelik, İngilizce öğretmenlerinin öncelikle ders verdikleri sınıf düzeylerine ve önceki kademelere yönelik, İngilizce Öğretim Programını ayrıntılı bir şekilde incelemeleri ve program içerisinde içeriğe uygun önerilen etkinlikleri derste kullanmaları önemlidir. Ayrıca öğretmenlerin, öğrencilerin dili gerçek yaşamla bağdaştırabilecekleri öğretim yöntem ve tekniklerinden haberdar olmaları ve bunları kullanmaları, öğretim programında yapılan değişiklikleri, reformları izlemeleri ve bunları sınıf içi-dışı ortamlarda öğretim sürecinde sıklıkla uygulamaları önerilebilir. Bulgulara göre, ders süresince İngilizcenin kullanımı, öğrencilerin dile maruz kalmalarını sağlayacak ortamlar oluşturmak açısından önemlidir.

Öğrencilere yönelik: Öğretmen rehberliğinde öğrencilerin, yabancı dili etkin bir şekilde kullanmaya dönük ortamları tercih etmeleri, teknolojiye ulaşabilmeleri yoluyla zengin dil öğrenme çevresi oluşturmaları, dört dil becerisini etkin kullanabilecekleri platformlardan haberdar olmaları önerilmektedir.

MEB ve okullara yönelik: Öğretim programında sunulan gerekli teknolojik alt yapıyı sağlamak üzere, okullar desteklenebilir. MEB ve okul yönetiminin bu anlamda iş birliği yoluna gitmesi önemlidir. Öğretim materyallerinin zamanında temini, eğitim-öğretim yılının başında tüm okulların benzer teknolojik donanıma ve alt yapıya sahip olmaları eğitimde firsat eşitsizliğinin ve dezavantajlı bölgelerde doğabilecek boşluğun kapatılması açısından değerlidir.

\section{Etik Kurul Kararı}

Bu araştırma, Hacettepe Üniversitesi Senatosu Etik Kurulu'nun 01/11/2017-562 tarih ve sayılı izni ile uygun bulunmuştur. 


\section{Kaynakça}

Albalawi, B. (2014). Effectiveness of teaching English subject using drama on the development of students' creative thinking. IOSR Journal of Research \& Method in Education (IOSR-JRME), 4(6), 54-63. http://www.iosrjournals.org/ adresinden erişilmiştir.

Alpar, M. (2013). The importance of games in teaching foreign languages to children. Academic Journals, 8(15), 1247-1255. doi: 10.5897/ERR2013.1494

Altay, B. (2018). Dokuzuncu sınıf İngilizce öğretim programının Hammond Küp modeli ile değerlendirilmesi (Yayımlanmamış doktora tezi). https://tez.yok.gov.tr/UlusalTezMerkezi/'nden erişilmiştir (Tez No. 517797).

Al-Zoubi, S. M. (2018). The impact of exposure to English language on language acquisition. Journal of Aplied Linguistics and Language Research, 5(4), 151162.

Arthur, M., and Blitz, C. (2000). Bridging the gap between science and practice in drug abuse prevention through needs assessment and strategic commun in planning. Journal of Community Psychology, 28, 241-255. doi: 10.1002/(SICI)1520-6629(200005)28:3<241::AID-JCOP2>3.0.CO;2-X

Aykaç, N. ve Ulubey, Ö. (2012). Öğretmen adaylarının ilköğretim programının uygulanma düzeyine ilişkin görüşleri. Journal of Faculty of Educational Sciences, 45(1), 63-82. https://www.researchgate.net/publication/285525707 adresinden erşilmiştir.

Backer, T. E. (2000). Finding the balance: program fidelity and adaptation in substanceabuse prevention: a state of the art review. Rockville, MD: Center for Substance Abuse Mental Health Services Administration.

Baydır, E. (2018). Ingilizce öğretmenlerinin 2017 taslak Ingilizce ögrretim programında yer alan değerler eğitimi ve uygulamalarına yönelik görüşleri (Yayınlanmamış yüksek lisans tezi). https://tez.yok.gov.tr/UlusalTezMerkezi/'nden erişilmiştir (Tez No. 511422).

Bosan, B. (2013, June 25). The effects of role-play on students' attitude and motivation to speak and interaction in the Esl classroom.(Unpublished Master Thesis). Faculty of Education Universiti Teknologi Malaysia, Malasia. Retrieved From: http://www.fp.utm.my/epusatsumber/pdffail/ptkghdfwP2/Bojeeswari\%20DO\% 20Bosan.TP.pdf

Bouaziz, S. (2015). The use of role-plays as a teaching technique to develop foreign language learners' oral proficiency. case study: Second year students at Biskra university.(Unpublished Master Thesis). Mohamed Kheider University of Biskra, Biskra, Algeria. 
Bümen, N., Yıldız, D., and Çakar, E. (2014). Curriculum fidelity and factors affecting fidelity in the Turkish context. Educational Sciences: Theory and Practice, 14(1), 203-228. doi: 10.12738/estp.2014.1.2020

Cook-Sather, A. (2006). "Sound,presence, and power:'student voice' in educational research and reform,".Curriculum Inquiry, 4(36), 359-390. doi: 10.1111/j.1467873X.2006.00363.X

Coşkun-Demirpolat, B. (2015). Türkiye'nin yabancı dil ögretimiyle imtihanı: sorunlar ve çözüm önerileri. Ankara: Yorum Basın Yayın Ltd.

Creswell, J. W. (2014). Research design: Qualitative, quantitative and mixed methods approaches. California: Sage Publications.

Dağhan, G., Kibar, N. P., Akkoyunlu, B., ve Atanur, B. G. (2015). Öğretmen ve yöneticilerin etkileşimli tahta ve tablet bilgisayar kullanımına yönelik yaklaşımları ve görüşleri. Turkish Journal of Computer and Mathematics Education, 6(3), 399-417. https://dergipark.org.tr/en/download/articlefile/201398 adresinden erișilmiștir.

Dane, A. V., and Schneider, B. H. (1998). Program integrity in primary and early secondary prevention: Are implementation effects out of control?. Clinical Psychology Review, 18(1), 23-45. doi:10.1016/S0272-7358(97)00043-3

Dusenbury, L., Brannigan, R., Falco, M., and Hansen, W. (2003). A review of research on fidelity of implementation:Implications for drug abuse prevention in school settings. Health Educ Res, 18(2), 237-256. doi:10.1093/her/18.2.237

Education First (2019). English proficiency index. Retrieved from https://www.ef.com.tr/epi/

Ersen-Yanık, A. (2017). A study of English language curriculum implementation $i$ n6th, 7th and 8th grades of public primary schools through teachers' and students' perceptions (Yayımlanmamış doktora tezi). https://tez.yok.gov.tr/UlusalTezMerkezi/'nden erişilmiştir (Tez No. 217824).

Fraenkel, J. R., and Wallen, N. E. (2012). How to design and evaluate research in education. New York: McGraw-Hill.

Gelmez-Burakgazi, S. (2019). Programa bağlılık: Kara kutuyu aralamak. Başkent University Journal of Education, 6(2), 236-249. http://buje.baskent.edu.tr/index.php/buje/article/view/189 adresinden erişilmiştir.

Gelmez-Burakgazi, S. (2020). Curriculum adaptation and fidelity: A qualitative study on elementary teachers' classroom practices. Issues in Educational Research, 30(3), 920-942. 
Gottfredson, G. D., Gottfredson, D. C., Czeh, E. R., Cantor, D., Crosse, S. B., and Hantman, I. (2000). National study of delinquency prevention in schools. Eilicott City, Maryland: Gottfredson Associates.

Guba, E. G., and Lincoln, S. (1982) Effective Evaluation, San Francisco.

Gürleyik, S., and Akdemir, E. (2018). Guiding curriculum development: Student perceptions $f$ or the second language learning in technology enhanced learning environments. Journal of Education and Training Studies, 6(4), 131-138. doi: 10.11114/jets.v6i4.2994

Hazarika, Z. (2017). Exploring the impact of technology in teaching English:Tesol in the context. European Journal of English Language and Literature Studies, 5(10), 19-28. www.eajournals.org adresinden erişilmiştir.

Haznedar, B. (2010). Türkiye'de yabancı dil eğitimi: reformlar, yönelimler ve ögretmenlerimiz. International Conference on New Trends in Education and Their Implications (ss. 747-755). Antalya: iconte.

Kırkgöz, Y. (2007). English language teaching in Turkey: Policy changes and their implementations. RELC Journal, 38(2), 216-228. doi: $10.1177 / 0033688207079696$

Kirkgöz, Y. (2008). A case study of teachers' implementation of curriculum innovation in English language teaching in Turkish primary education. Teaching and Teacher Education, 24(7), 1859-1875. doi:10.1016/j.tate.2008.02.007

Krrivková, L. (2011). Design of the workshop:how to use drama in an English language class? (Unpublished Diploma Thesis). Retrieved from https://is.muni.cz/th/151036/pedf_m/Krivkova-Drama-final.pdf

Kuśnierek, A. (2015). Developing students' speaking skills through role-play. World Scientific News, 7, 73-111. http://www.worldscientificnews.com/ adresinden erişilmiştir.

Liu, F., and Ding, Y. (2009). Role-play in English language teaching. Asian Social Science, 5(10), 140-143. doi: 10.5539/ass.v5n10p140

Lynch, S. (2002). A model for fidelity of implementation in a study of a science curriculum unit:Evaluation based on program theory. (Bu çalışma Amerikan Eğitim Araştırmaları Derneğinin yıllık toplantısında sunulmuştur.), San Francisco: CA.

McKay, S. (2002). Teaching English as an international language: rethinking goals and approaches. Oxford: Oxford University Press.

MEB. (2005). Ortaöğretim İngilizce öğretim programı. Ankara: Milli Eğitim Bakanlığı. 
MEB. (2012). Ortaöğretim İngilizce öğretim programı. Ankara: Milli Eğitim Bakanlığ.

MEB (2017a). Ortaöğretim İngilizce öğretim programı. Ankara:Milli Eğitim Bakanlığı.

MEB (2017b). 2017 Meb bası açıklaması. (https://ttkb.meb.gov.tr/meb_iys_dosyalar/2017_07/18160003_basin_aciklama si-program.pdf)

MEB (2018). Ortaöğretim İngilizce öğretim programı. Ankara: Milli Eğitim Bakanlığı.

Nishanthi, R. (2018). The importance of learning English in today world. International Journal of Trend in Scientific Research and Journal, 3(1), 871874. doi: 10.31142/ijtsrd19061

O'Donnell, C. L. (2008). Defining, conceptualizing, and measuring fidelity of implementation and its relationship to outcomes in $\mathrm{K}-12$ curriculum intervention research. Review of Educational Research, 78(1), 33-84.doi: $10.3102 / 0034654307313793$

Özer, B. ve Korkmaz, C. (2016). Yabancı dil öğretiminde öğrenci başarısını etkileyen unsurlar. Ekev Akademi Dergisi, 67, 59-84.

Öztürk, E. (2003). An assessment of high school biology curriculum implementation (Unpublished doctoral thesis). Retrieved from https://tez.yok.gov.tr/UlusalTezMerkezi/ (Tez No. 140136).

Paker, T. (2012). Türkiye'de neden yabancı dil (İngilizce) öğretemiyoruz ve neden öğrencilerimiz iletişim kurabilecek düzeyde İngilizce öğrenemiyor? Pamukkale Üniversitesi Ĕ̈itim Fakültesi Dergisi, 32, 89-94.

Pasovic-Petrovic, E. (2014). Games in the language classroom-to pay is to learn. (Unpublished Master Thesis), Retrieved From: https://muep.mau.se/bitstream/handle/2043/17961/Ema\%20EX\%202014\%20P DF.pdf

Paulikova, K. (2018). Teaching speaking through dialogues, discussions and roleplays. Slavonic Pedagogical Studies Journal, 7(1), 201-214.

Reddy, M. S. (2016). Importance of English language in today's world. International Journal of Academic Research, 4(2), 179-184. www.ijar.org.in adresinden erişilmiştir.

Roman, V. R. (2016). The importance of fidelity of implementation and factors that impede it for teachers: an interpretative phenomenological analysis. (Unpublished Doctoral Thesis), Retrieved From: https://repository.library.northeastern.edu/files/neu:cj82pr32v/fulltext.pdf 
Seraj, P. M., and Mamun, M. A. (2011). Speaking and listening practice in English language learning through communicative language teaching at hsc level. $G$ Science Implementation and Publication, 2(4), 7-12.

Sneddon, J. (2003). The Indonesian language, its history and role in modern society. Sdney: Nsw press.

Songer, N. B., and Gotwals, A. W. (2005). Fidelity of implementation in three sequential curricular units. Paper presented at the AERA (American Education Research Association, Canada.

Şavran, E. (2017). Mesleki ve teknik anadolu llisesi öğretmen ve ögrrencilerinin Ingilizce öğretim programının etkililiğine ilişkin alglları: Osmaniye ili örnĕ̆ (Yayınlanmamış yüksek lisans tezi). https://tez.yok.gov.tr/UlusalTezMerkezi/'nden erişilmiştir (Tez No. 485591).

Tekbıyık, A. ve Akdeniz, A. R. (2008). İlköğretim fen ve teknoloji dersi öğretim programını kabullenmeye ve uygulamaya yönelik öğretmen görüşleri. Necatibey Ĕgitim Fakültesi Elektronik Fen ve Matematik Eğitimi Dergisi, 2(2), 23-37. https://dergipark.org.tr/tr/pub/balikesirnef/issue/3367/46487 adresinden erişilmiştir.

Wang, S. (2006). Applicability and transferability of interventions in evidence-based public health. Health Promotion International, 21(1), 76-83. doi:10.1093/heapro/dai025

Wiles, J., and Bondi, J. (2007). Curriculum development: A guie to practice (7th ed.) Upper Saddle River, NJ: Pearson.

Yıldırım, A. ve Şimşek, H. (2003). Sosyal bilimlerde nitel araştırma yöntemleri. Ankara: Seçkin Yayınları.

Yin, R. K. (2003). Case study research design and methods (3rd edition). London: Sage publications.

Yüce, E. (2018). Türkiye'deki lise 9.sınıf İngilizce öğretim programının Avrupa dilleri ögretimi ortak çerçeve programı ilkelerine göre değerlendirilmesi (Yayınlanmamış doktora tezi). https://tez.yok.gov.tr/UlusalTezMerkezi/'nden erişilmiştir (Tez No. 515660).

Yücel, E., Dimici, K., Yıldız, B. ve Bümen, N. T. (2017). Son 15 y1lda yayımlanan ilk ve ortaöğretim İngilizce dersi öğretim programları üzerine bir analiz. Ege Ĕ̈itim Dergisi, 2(18), 702-737. doi: 10.12984/egeefd.305922 


\title{
A Case Study on the Secondary School English Curriculum: Teacher's Fidelity and Students' Expectations
}

\begin{tabular}{cccc}
\hline ARTICLE TYPE & Received Date & Accepted Date & Published Date \\
Research Article & 02.25 .2020 & 05.23 .2021 & 06.14 .2021 \\
\hline Esra Civriz iD 1 & \\
Ministry of National Education & \\
& Sevinç Gelmez Burakgazi & \\
Hacettepe University 2
\end{tabular}

\begin{abstract}
This research aims to analyze students' expectations and, achievement in different language skills in the Secondary School English Language Curriculum which renewed in 2017 and gradually implemented in the 9th grade. The curriculum was implemented with teacher's fidelity to the new curriculum. The research was carried out with 65 students at 9th grade level in a public school in one of Kastamonu districts. Data were collected through students' expectation questionnaire, mid-term evaluation questionnaire, and final assessment questionnaire developed by researchers. Multiple case holistic design was used in this research. Within the scope of document analysis, the English curriculum, students' exams, and teacher's notes were analyzed. The research data were analyzed with descriptive analysis. According to the results, it was seen that students expected to improve mostly on their listening and speaking skills, and they were willing to participate, educational activities such as role-play and educational games. Moreover, students expected the lessons to be conducted in English language. Considering the data analysis, it was concluded that the expectations of the students were met in the class of the teacher, who conducted the courses with the fidelity of the renewed curriculum by supporting the themes of the program with the proposed activities and materials in the suggested period of time.
\end{abstract}

Keywords: Curriculum fidelity, English curriculum, English teachers, foreign language learning, students' expectations

The Ethical Committee Approval: This research has been approved by the permission of Hacettepe University Ethics Board dated 01/11/2017- 562.

\footnotetext{
${ }^{1}$ Corresponding Author: Teacher, Kastamonu/Turkey, e-mail: esracvrz@hotmail.com, https://orcid.org/0000-0002-8065-5562

${ }^{2}$ Assist. Prof., Faculty of Educational Sciences, Curriculum and Instruction, e-mail: sevincgelmez@gmail.com, https://orcid.org/0000-0002-4553-1433
} 


\section{Purpose and Significance}

The necessity of being informed about scientific, political, economic and sociocultural developments all over the world is one of our comminity's daily needs. One of the main channels in order to meet these needs, is to communicate with the other countries regularly and consistently. Communication is of great importance to follow the scientific, political, economic and sociocultural developments all over the world. In this sense, curricula take the responsibility of reflecting these sociocultural, economic and scientific developments all over the world into the education. The curriculum has national and international missions such as development of the countries, growing up to contemporary societies, catching up the rapid changes and economic situations in the world and etc. In order to put into practice these goals, the most important step is to engage education and curriculum. Education shapes not only the individuals but also the whole society. Education needs to take the social, cultural, economical, and political changes into consideration in the world. In order to make these goals real and visible, education systems use curricula and education programs. On the first side, the changes in the world and the country can be reflected in the education programs to make those goals real and alive at schools. At this juncture, education programs are renewed and reformed to the changes in the countries and in the world. These changes are reflected in the curriculum. The curriculum has stakeholders like teachers, students, administrators or etc. As a stakeholder, teachers are responsible for applying the curriculum in the classroom and reflecting the changes to the classroom environment. Teachers are also responsible for making a decision on the activities they will use and, the changes in the implementation when it requires. In this step, curriculum fidelity is important. Teachers are expected to reflect all the reforms and regulations to the classrooms in the curriculum. Another stakeholder is students. Students have great importance to make the curriculum alive in the environment of the classroom. Students' expectations from the curriculum are also crucial. With the help of the students' expectations, the curriculum can be made more beneficial and functional. This study aims to analyze students' expectations from the renewed Secondary School 9th Grade English Language curriculum and teacher's fidelity to the curriculum. In this study, students' expectations were investigated when the teacher implemented renewed 9th grade English language curriculum with fidelity. At the same time, students' achievements and how well students' expectations were met had been investigated. Within this purpose, research questions are as follows:

In the English lessons implemented with teacher's fidelity to the renewed secondary school 9 th grade curriculum,

1. What are the students' expectations from the English lessons?

2. At the beginning of the term, are the students' listening and speaking skills at the level specified in the program?

3. At the end of the term, are the students' expectations met from the renewed curriculum? 
4. At the end of the term, are the students' listening, speaking, reading and writing skills at the level specified in the program?

\section{Method}

The study was carried out during the fall term of the 2017-2018 academic year. The sample was composed of 65 ninth grade students. In this study, multiple caseholistic design was used. The researcher used this method by focusing the student' expectations from the renewed 9th grade secondary school English language curriculum.

Before the collection of data, this research has been approved by the permission of Hacettepe University Ethics Board dated 01/11/2017-562. After all the ethical permission was completed, the data collection process started. Data was collected through students' expectation questionnaire, mid-term evaluation questionnaire, and final assessment questionnaire developed by researchers. Within the scope of document analysis, the English curriculum, students' exams, and teacher's notes were analyzed. The research data was analyzed with descriptive analysis. In the first part of the study, in order to identify the students' expectations, a students' expectation questionnaire was used. It consisted of four questions related to English course contents. Additionally, listening and speaking quizzes were used to see the students' exact level in the speaking and listening skills at the beginning of the term. In the listening quiz, the song was listened by the students and made them fill in the blanks some of the specific words were chosen intentionally by the teacher in line with the course objectives. In the speaking quiz, the teacher made students give directions. In the second part of the study, a mid-term evaluation questionnaire was used in order to investigate students' ideas and feelings about the English lessons, content, methods, and evaluation techniques. In this form, four questions were asked and it took fifteen minutes to apply. In the first and second exams, first, second and third unit contents, grammatical topics, vocabularies were asked. In the last part of the study, the practice exam was used and, in this exam, there were four language skills which were listening, speaking, reading, writing. Every part of the exam had equal points. In the last part of the study, the final assessment questionnaire was used in order to see whether the students' expectations met or not.

\section{Results}

The results of the study revealed that (1) the students expressed that the number of role plays, activities and games should be increased, practice makes the English language learning better, how much they practice and experience the language, how much they will learn (2) the students mostly preferred communicative skills such as speaking and listening, they are aware of the importance of English and in order to get the real aim of this, they need specific English communicative skills (3) students preferred their teacher to carry out lessons in English than Turkish language. Exposure to the target language motivated students in language learning. It was concluded that with the help of different activities, practices and games, students learnt English easily and it was concluded that when the language was oriented with practice, it was more 
communicative, (4) students preferred being increased dialogues and discussion activities in the English classrooms, these activities provided them use language effectively, (5) limited technological materials was a hinder for the teacher in the classroom to liven up the courses (6) at the end of the term, students reached the expected and planned level in the 9th grade English language curriculum, they also got the aims and objectives appropriately with the English language curriculum as it was planned time and date, (7) the expectations of the students were met in the class of the teacher, who conducts the courses with curriculum fidelity by supporting the themes of the program with the proposed activities and materials in the planned period of time.

\section{Discussion and Conclusion}

It can be concluded that all the curriculum was implemented with fidelity with aims, content, teaching-learning activities and evaluation in the planned period of time. One of the drawbacks was the lack of technology at school and made it difficult to reach technology and the technological materials in the English classes during the teaching-learning processes. In secondary school English language curriculum, technology and technological materials, activities and methods have great importance (MEB, 2018). When considered the students' expectations, it can be concluded that one of the main expectations of the students in English classes was to use this language in the four main skills, especially with speaking and listening. According to the results of the study, it can be surely concluded communication in targeted language make students more active in the classroom. Students preferred mostly speaking and listening activities in the classrooms. One of the fundamental results of this study was that students mostly enjoyed in drama, dialogues, discussion activities and games in English classes. According to Bouaziz (2015), it is believed that games and drama provide real contexts. Krrivková (2011) expresses that teaching the language in real contexts feeds the students in two ways; it teaches both real culture and real activities. Using these activities and methods for teaching foreign language make the lessons more interesting and motivating for both learners and teachers (Paulikova, 2018). It can be inferred from this result that these methods and techniques may provide teaching the target language in its context and in its nature. Based on the results, teaching English language only by using English language in the classroom environment has great importance. Al-Zoubi (2018) states that being exposed to the target language in the classroom environment during the lessons makes students acquire the language effectively. As a consequence, the results indicated that students got higher achievement and their expectations were highly met with the fidelity to the renewed 9th grade curriculum.

\section{The Ethical Committee Approval}

This research has been approved by the permission of Hacettepe University Ethics Board dated 01/11/2017- 562. 